\title{
THE ORB-WEAVER GENERA SINGA AND HYPSOSINGA IN AMERICA (ARANEAE: ARANEIDAE)*
}

\author{
By Herbert W. Levi
}

\section{Museum of Comparative Zoology, Harvard University}

The North American spiders commonly placed in Singa belong to four different genera. It was first thought best to publish on these species together with the small species of Araneus. However, the slowness with which the Araneus studies proceed makes it advisable to publish on Singa and Hypsosinga first.

Most of the specimens of these genera belonging to the American Museum appear to be lost and only small collections other than those of the Museum of Comparative Zoology were available. I would like to thank the following for loan of additional specimens: Dr. J. A. Beatty; Mr. D. E. Bixler; Mr. D. Buckle; Dr. J. A. L. Cooke for collections of the American Museum of Natural History and Cornell University; Dr. R. Crabill for specimens from the U.S. National Museum; Dr. B. Cutler; Dr. C. D. Dondale of the Canada Dept. of Agriculture; Dr. B. J. Kaston; Dr. W. W. Moss for collections from the Academy of Natural Sciences, Philadelphia; Dr. W. Peck for specimens from the Exline collection; Dr. J. Prószynski for collections of the Polish Academy of Sciences; Miss Susan Riechert; Mr. V. Roth; Dr. W. Shear; Dr. C. Triplehorn of Ohio State University; Prof. S. L. Tuxen for specimens from the Zoological Museum of the University of Copenhagen; Dr. J. D. Unzicker for specimens from the Illinois Natural History Survey; Prof. M. Vachon and Dr. M. Hubert for collections of the Muséum National d'Histoire Naturelle, Paris; Dr. B. Vogel; and Dr. H. K. Wallace. I am also indebted to Mr. J. Denis, Mr. G. Pühringer, and especially to Miss Susan Riechert for helpful information. The research and publication were supported by Public Health Service Grant AI-or944 from the National Institute of Allergy and Infectious Diseases.

$$
\text { Singa C. L. Koch }
$$

Singa C. L. Koch, 1836, Arachniden, vol. 3, p. 42. Type species Singa hamata (Clerck) designated by Thorell, 1869. On European Spiders, p. 58. The name is of feminine gender.

Diagnosis. The anterior median eyes are the largest, the posterior medians the same size or smaller, the laterals about 0.6 diameter of the anterior medians. In Singa the median ocular quadrangle is wider

\footnotetext{
*Manuscript received by the editor February 8, 1972.
} 
in front (Figs. 20, 30); in Hypsosinga it is rectangular or wider behind. The carapace of the female is shiny and has no thoracic depression (Figs. 22, 32); in the male it has a short longitudinal line. The first coxa of the Singa male, unlike that of the $H_{y}$ psosinga male, has a hook on the side. The height of the clypeus is equal to or less than the diameter of the anterior median eyes (Figs. 20,30); in Hypsosinga it is higher. The second tibia of the Singa male may be modified; in Hypsosinga the first tibia may be modified. In Singa the sides of the abdomen are almost parallel and the abdomen overhangs the spinnerets. There are two dorsal longitudinal black bands on the abdomen of Singa (Figs. 21, 22, 31, 32).

The female genitalia differ from those of Hypsosinga in that Singa has a scape on the epigynum (Figs. 6, I I, 25). The palpus of the Singa male has an enormous terminal apophysis (A in Figs. $3,5,9)$, ending in a sclerotized spine and located in the contracted palpus on the outer side of a rather narrow tegulum (Fig. 5). Below the terminal apophysis, a heavily sclerotized hook, perhaps the subterminal apophysis (SA in Figs. I, 3, IO), lies hidden in the contracted bulb. The embolus may have a lamella (Figs. I, 9); it does not seem to have a part that breaks off in mating. The stipes (I in Fig. I) is a distinct sclerite in $S$. hamata, but is apparently fused to the embolus in $S$. keyserlingi (Fig. 9). The tegulum is widest near the base of the conductor (Figs. 2, 3, 10).

Natural History. Surprisingly little is known about the habits of Singa. They make a complete orb. Nielsen (1932, Biology of Spiders, 2; fig. 330) has a picture of the retreat of $S$. hamata. Both American species prefer moist locations, and adults are found throughout the season. G. Pühringer (personal communication) told me that Singa phragmiteti Nemenz is common on reeds along the Neusiedler See in Austria. It prefers a site above water and has to be collected from a boat. I suspect that American species have similar habits, which may account for the few specimens in collections.

Distribution. Species are known only from Eurasia and temperate North America. All others described are probably misplaced.

Misplaced American Species. (This list of names follows Roewer, 1942, Katalog der Araneae. The types of the species, unless indicated otherwise, have been examined. Species placed in Hypsosinga are not listed.)

abbreviata Keyserling, $1879=$ Theridiosomatidae.

bengryi Archer, $1958=$ Metepeira bengryi (Archer), new combination. 
calix Walckenaer, ${ }^{8} 84 \mathrm{I}=$ Alpaida calix, new combination.

crewii Banks, I903; the type is lost, the description is not recognizable.

dotana Banks, $\mathrm{I914}=$ Theridion dotanum.

duodecimguttata Keyserling, I879 = Alpaida duodecimguttata

(Keyserling), new combination.

erythrothorax Taczanowski, I873 = Alpaida erythrothorax (Taczanowski), new combination.

essequibensis Mello-Leitão, I948 = ?Alpaida essequibensis, type specimens unavailable.

Alava O. P.-Cambridge, $\mathrm{I}_{894}=$ Araneus flavus (O. P.-Cambridge).

floridana Banks, $\mathrm{I} 896=$ Araneus floridana (Banks).

leucogramma White, $\mathrm{I} 84 \mathrm{I}=$ Alpaida leucogramma (White), new combination.

listerii McCook, $\mathrm{I} 893=$ Araneus pratensis Emerton.

longicauda Taczanowski, I878 = generic placement uncertain.

marmota Taczanowski, $1873=$ Alpaida marmorata (Taczanow-

ski), new combination.

maura Hentz, i $847=$ Alpaida calix Walckenaer.

moesta Banks, I 893 . The type has been destroyed, the description cannot be recognized.

mollybyrnae McCook, I893 = Metazygia pallidula (Keyserling).

NEW SYNONYMY. Type locality in error; not District of Columbia, probably Colombia.

niveosigillaa Mello-Leitão, $\mathrm{I94 \textrm {I }}=$ ?Alpaida niveosigellata, type specimens unavailable.

pratensis Emerton, $\mathrm{I}_{84}=$ Araneus pratensis (Emerton).

praticola Simon, $\mathrm{I} 895=$ Araneus pratensis (Emerton).

tremens Holmberg, I876. The type has been destroyed.

vanbruysseli Becker, $1879=$ Cyclosa turbinata (Walckenaer), NEW SYNONYMY.

vittata Taczanowski, I873. The type is lost.

The two common species north of Mexico, calix and pratensis, are obviously misplaced. Judging by the structure of the genitalia, Singa pratensis is close to Araneus sturmi ( $\mathrm{Hahn}$ ) of Europe. Differences are the shape of the abdomen and lack of body setae, but the shape, setation, and coloration of the abdomen are quite variable in the many species of these small Araneus. Araneus sturmi is the type species of the genus Atea. At present it does not seem wise or even feasible to fragment the genus Araneus. It would lead to 
proliferation of names without meaning for relationships. They are obviously monophyletic.

Singa calix belongs to a South American genus, one of the largest genera of orb weavers in the Americas. As far as I know at present, the oldest name is Alpaida O. P.-Cambridge, I889. But numerous other generic names have been used for this genus; Lariniacantha Archer (1951, Amer. Mus. Novitates, no. 1487, p. I5) most recently. The genus is much closer to Acanthepeira than to Singa. However, I am still hestitant about the placement until I have more knowledge of the webs and habits of the species in the genus.

Key to American Species of Singa

Ia. Base of epigynum trapezoidal, with sides sclerotized (Figs. I II4) ; median apophysis of palpus with one hook (Figs. 23, 24) keyserlingi

Ib. Base of epigynum with a lobe on each side (Fig. 25); median apophysis of palpus with two hooks (Figs. 33, 34) ....... eugeni

\section{Singa hamata (Clerck) \\ Figures I-8}

Araneus hamatus Clerck, 1757, Aranei Svedici, p. 51, pl. 3, fig. 4. Female type specimens from Sweden believed lost. Bonnet, 1955, Bibliographia Araneorum, vol. 2, p. 513.

Singa hamata, - C. L. Koch, 1836, Die Arachniden, vol. 3, p. 42, figs. 197, 198, 우 $\hat{o}$. Wiehle, 1931, in Tierwelt Deutschlands, vol. 23, p. 42, figs. 54-57, $q$, $\hat{o}$. Roewer, 1942, Katalog der Araneae, vol. 1, p. 873. Locket and Millidge, 1953, British Spiders, vol. 2, p. 157, figs. 102b, $103 \mathrm{c}, 105 \mathrm{c}$, 우,$\hat{o}$.

This species, very similar to the two American ones, is known only from Eurasia.

\section{Singa keyserlingi McCook \\ Figures 9-24, Map I}

Singa keyserlingi McCook, 1893, American Spiders, vol. 3, p. 230, pl. 19, fig. 2, 9 . Female holotype from St. Louis, Missouri, in the Academy of Natural Sciences, Philadelphia; examined and labelled as type.

Singa campestris Emerton, 1915, Trans. Connecticut Acad. Sci., vol. 20, p. 153, pl. 3, fig. 3, $\hat{\delta}$. Male syntype from Rat Portage, Ontario, in the Museum of Comparative Zoology; examined. NEW SYNONYMY.

Note. McCook described S. keyserlingi as a new species. However, in the first paragraph of the description he finds it necessary "to propose a new name" for the species Keyserling illustrated and called erroneously Singa rubella (Hentz). The specimens Mc:Cook 


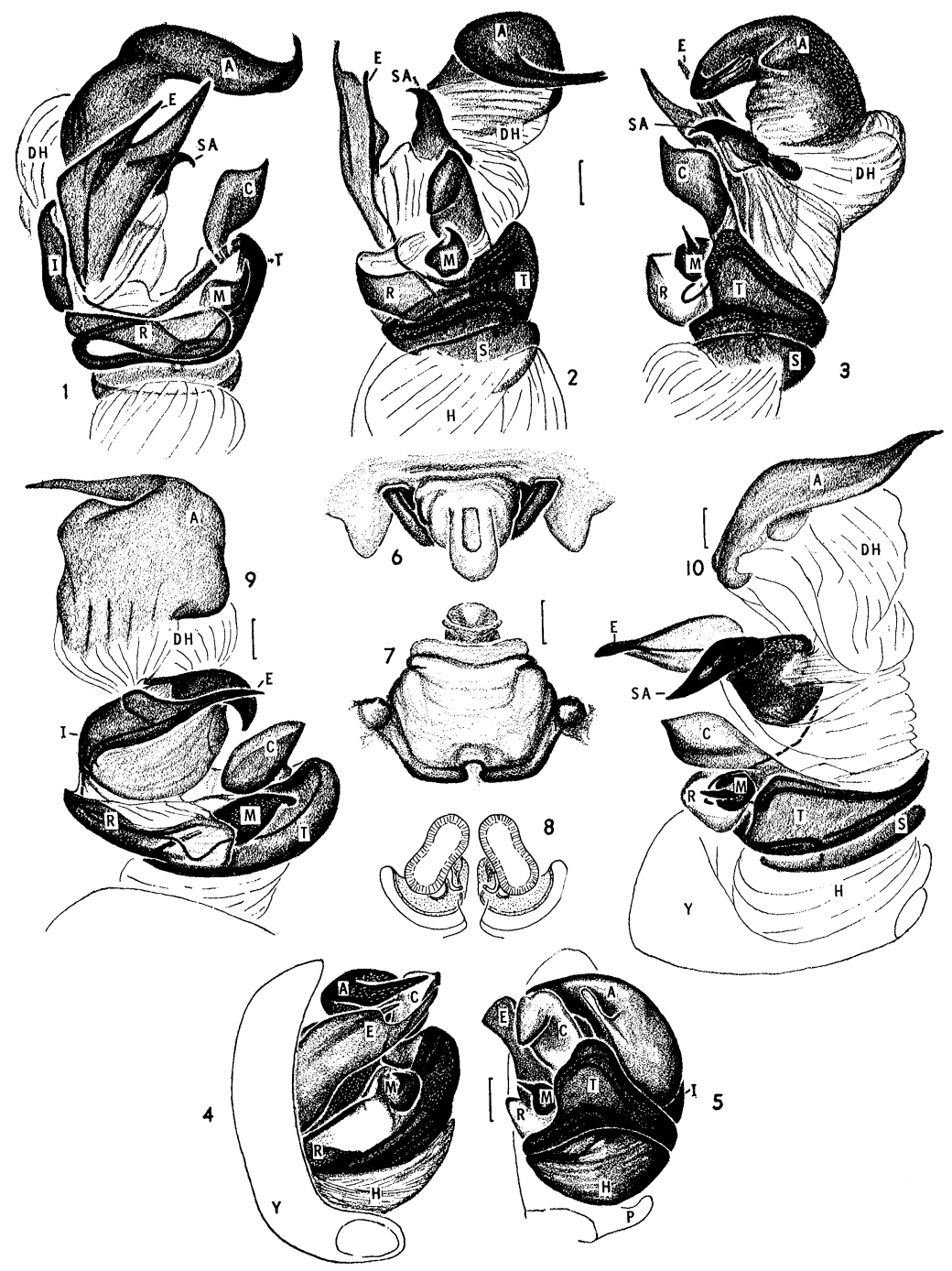

Figs. 1-8. Singa hamata (Clerck). 1-5. Left palpus. 1-3. Expanded. 4. Mesal view. 5. Ventral view. 6-8. Epigynum. 6. Ventral. 7. Posterior. 8. Dorsal.

Figs. 9-10. Singa keyserlingi McCook, palpus, expanded.

Abbreviations: A, terminal apophysis; C, conductor; DH, distal hematodocha; E, embolus; $\mathrm{H}$, basal hematodocha; I, stipes; $\mathrm{M}$, median apophysis; P, paracymbium; $R$, radix; S, subtegulum; SA, subterminal apophysis; $T$, tegulum; Y, cymbium.

Size Indicators: $0.1 \mathrm{~mm}$. 
had on hand and figured were specimens of what is here considered to be $S$. keyserlingi, and not what Keyserling called rubella.

In the United States National Museum there is a specimen marked Singa rubella Hentz, St. Louis, Mo., collected by Marx. Another label in the vial reads "Cotype I688 U.S.N.M." The specimen contained is a female of what is here called $S$. eugeni, and there is no evidence that it is a syntype of $S$. keyserlingi McCook. McCook reports having seen specimens from the District of Columbia in the Marx collection. Keyserling also reports that the Singa rubella he examined came from the District of Columbia from the Marx collection.

Figure I3 was prepared from the type of $S$. campestris.

Description. Female from Wisconsin. Carapace orange; head region, clypeus black. Chelicerae, labium, endites dark brown. Sternum orange. Legs orange, distal articles darker. Dorsum of abdomen with two wide black bands separated by a narrow white band (Fig. 22). Sides of black bands have lateral white band (Fig. 2I). Venter has a black patch which may have a white line on each side. Anterior median eyes slightly more than one diameter apart, one diameter from laterals. Posterior median eyes their radius apart, two and one-half diameters from laterals. Total length $5.5 \mathrm{~mm}$. Carapace $2.4 \mathrm{~mm}$ long, $\mathrm{I} .7 \mathrm{~mm}$ wide. First femur, $\mathrm{I} .4 \mathrm{~mm}$; patella and tibia, $2.1 \mathrm{~mm}$; metatarsus, $1.3 \mathrm{~mm}$; tarsus, $0.7 \mathrm{~mm}$. Second patella and tibia, $1.9 \mathrm{~mm}$; third, $1.3 \mathrm{~mm}$; fourth, $1.7 \mathrm{~mm}$.

Male from Wisconsin. The coloration is like that of the female except that black on the head seems limited to the eye region. The chelicerae are black only distally, orange at the base. The dorsum of the abdomen is all black. The anterior median eyes one and onethird diameters apart, one diameter from laterals. Posterior median eyes their radius apart, two and one-half diameters from laterals. The palpal patella has two weak macrosetae. The first and second legs have strong macrosetae on prolateral surface, but are not bent or swollen. Total length $3.9 \mathrm{~mm}$. Carapace $2.2 \mathrm{~mm}$ long, I. $6 \mathrm{~mm}$ wide. First femur, $1.5 \mathrm{~mm}$; patella and tibia, $2.0 \mathrm{~mm}$; metatarsus, I. $4 \mathrm{~mm}$; tarsus, $0.7 \mathrm{~mm}$. Second patella and tibia, $\mathrm{r} .8 \mathrm{~mm}$; third, I.2 $\mathrm{mm}$; fourth, $1.5 \mathrm{~mm}$.

Variation. In the female the scape of the epigynum varies greatly in length and shape (Figs. II-15); the internal ducts may be either heavily sclerotized or transparent, sac-like and difficult to make out. Females vary from $5.1-6.0 \mathrm{~mm}$ in total length, carapace $1.5-1.7 \mathrm{~mm}$ 

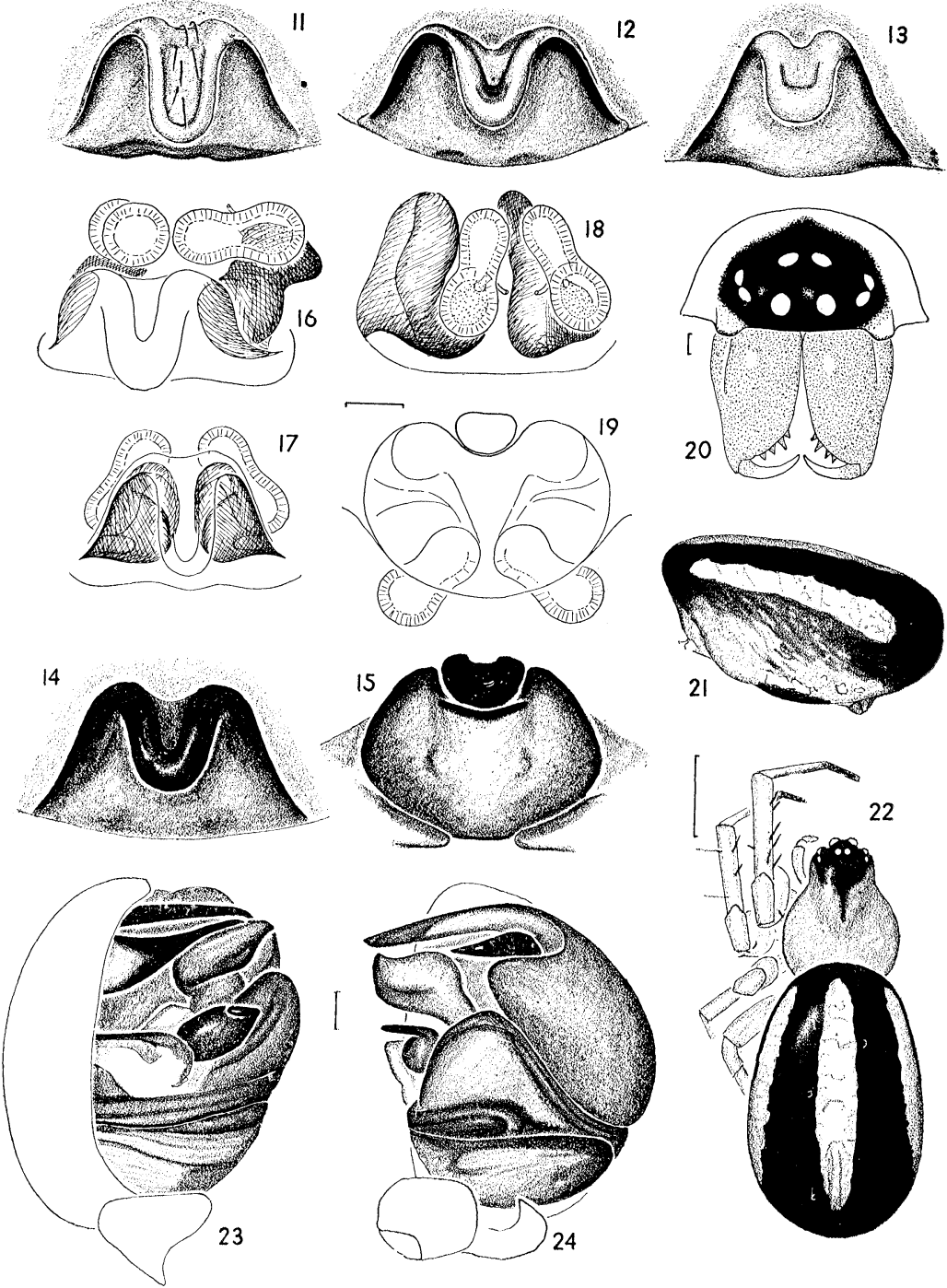

Figs. 11-24. Singa keyserlingi McCook. 11-22. Female. 11-19. Epigynum. 11-14. Ventral. 11. (Illinois). 12. (Wisconsin). 13. (Ontario). 14, 15. (South Dakota). 15. Posterior. 16-19. Cleared. 16. Subventral. 17. Ventral. 18. Dorsolateral. 19. Posterior. 20. Face. 21. Abdomen, lateral. 22. Dorsal. 23-24. Left palpus. 23. Mesal. 24. Ventral.

Size Indicators: $0.1 \mathrm{~mm}$, except for Figs. 21-22, $1 \mathrm{~mm}$. 
wide. Males vary from $2.3-4.0 \mathrm{~mm}$ in total length, carapace I.3-1.6 mm wide.

Diagnosis. Females differ from those of $S$. eugeni in the shape of the base of the epigynum, trapezoidal with the lateral margins sclerotized (Figs. II-I4). The male differs from that of $S$. eugeni by having only one hook on the median apophysis (Figs. 23, 24).

Natural History. Singa keyserlingi has been collected from open woods, in low shrubs and by sweeping grass on lakeshores. Mature males have been collected in all months between May and August. Females have been collected through September.

Distribution. From Edmonton, Alberta, Smoky Falls, Ontario to Black Warrior National Forest (Winston Co.), Alabama (Map I).

\section{Singa eugeni sp. $n$. \\ Figures 25-34, Map I}

Singa rubella,-Keyserling, 1893, Spinnen Amerikas, vol. 4, p. 284, pl. 14, fig. 209, ㅇ. Not Epeira rubella Hentz.

Type. Male holotype and female paratype from $\mathrm{T} 8 \mathrm{~N}, \mathrm{R}_{5} \mathrm{E}$, S9NWI/4, Iowa County, Wisconsin (Susan Riechert), in the $\mathrm{Mu}-$ seum of Comparative Zoology. The species is named after Count Eugen Keyserling.

Description. Female. Carapace orange with a wide black band covering eye region (Fig. 32), narrowing behind. Clypeus black. Chelicerae brown-black. Labium black. Sternum yellowish with dark brown margin. Legs yellow. Dorsum of abdomen with two longitudinal dark bands; at each end the bands are darker and approach each other (Fig. 32). The bands are separated by a white pigment line. The sides are white (Fig. 3I); the venter is yellowish with an indistinct dark area in the middle. The anterior median eyes are one and one-quarter diameters apart, less than one diameter from laterals. Posterior median eyes are less than one-quarter diameter apart, one and one-half diameters from laterals. Total length 4.6 $\mathrm{mm}$. Carapace $2.0 \mathrm{~mm}$ long, $\mathrm{I} .4 \mathrm{~mm}$ wide. First femur, $\mathrm{I} .3 \mathrm{~mm}$; patella and tibia, $2.2 \mathrm{~mm}$; metatarsus, $\mathrm{I} .2 \mathrm{~mm}$; tarsus, $0.6 \mathrm{~mm}$. Second patella and tibia, I.9 mm; third, $1.2 \mathrm{~mm}$; fourth, $1.7 \mathrm{~mm}$.

Male. The coloration of the male is like that of female. The carapace is narrower in front than in the female. The anterior median eyes overhang the chelicerae. The anterior median eyes are more than one diameter apart, their radius from laterals. The pos- 


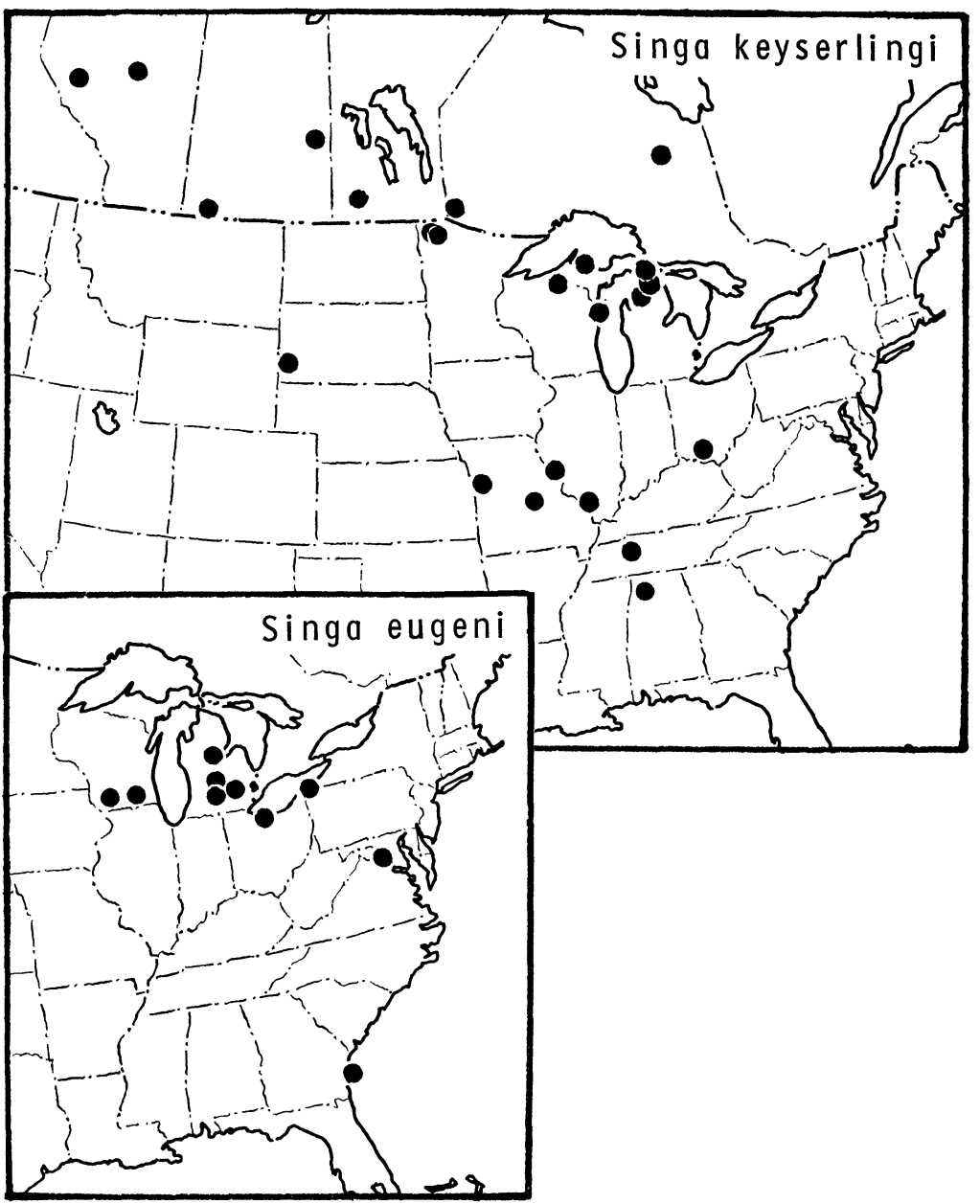

Map. 1. Distribution of Singa keyserlingi (McCook) and S. eugeni sp. n. 
terior median eyes are one-quarter diameter apart, one and one-half diameters from laterals. The second tibia is thick, slightly curved, with macrosetae on prolateral side, but only very slightly modified. The palpal patella has one strong and one very weak seta. There are eight black, sclerotized dorsal muscle attachments on the abdomen. Except for the narrower carapace, the male looks like the female. Total length $5 \mathrm{~mm}$. Carapace $2.2 \mathrm{~mm}$ long, $1.6 \mathrm{~mm}$ wide. First femur, $2.2 \mathrm{~mm}$; patella and tibia, $3.4 \mathrm{~mm}$; metatarsus, 2.3 $\mathrm{mm}$; tarsus, $0.9 \mathrm{~mm}$. Second patella and tibia, $2.9 \mathrm{~mm}$; third, $\mathrm{I} .4$ $\mathrm{mm}$; fourth, $1.9 \mathrm{~mm}$.

Variation. In some individuals only four black spots remain of the two abdominal bands, two anterior and two posterior. If present the soft projection from the terminal apophysis, seen in ventral view (Fig. 34), may be either a flap or a rod. Females are from 4.3$6.5 \mathrm{~mm}$ in total length, carapace I.I-1.6 mm wide; males are from 3.6-5.4 $\mathrm{mm}$ in total length, carapace I.2-1.8 mm wide.

Diagnosis. Females are distinguished from those of $S$. keyserlingi by the smaller epigynum with a lobe on each side of scape (Fig. 25), as opposed to a sclerotized diagonal margin seen in $S$. keyserlingi. The median apophysis of the palpus has two hooks, one on each end (Figs. 33, 34). In the related $S$. nitidula of Europe the median apophysis is of different shape and the embolus narrower.

Natural History. Wisconsin specimens came from open bottomland forest, along backwaters of river edges, and edge of marsh; Georgia specimens came from Spartina stems. Barrows (I9I8, Ohio J. Sci., I8: 310) reported that a Singa from Cedar Point, Ohio, almost certainly this species, made "a small orb in tops of dune grass (Andropogon). During the day it stays in the hollow stems of dead grass." The spiders have also been collected in Pennsylvania by the wasp Episyron quinquenotatus (Say). The males are mature in September and October in the north. Adult females have been collected from May to October.

Localities collected. Pennsylvania; Erie Co.: Presque Isle State Park. Ohio. Erie Co.: Cedar Point. D.C. Washington. Georgia. McIntosh Co.: Sapelo Island. Michigan. Clinton Co.: Rose Lake. Eaton Co.: Calumet. Livington Co.: George Reserve. Midland Co. Wisconsin. Iowa Co.: $\$$, $0^{\pi}$ paratypes. Jefferson Co. (Map r).

\section{Hypsosinga Ausserer}

Hypsosinga Ausserer, 1871, Verhandl. Zool. Bot. Gesell. Wien, vol. 21, p. 823 (subgenus). Type species Singa sanguinea (C. L. Koch) 


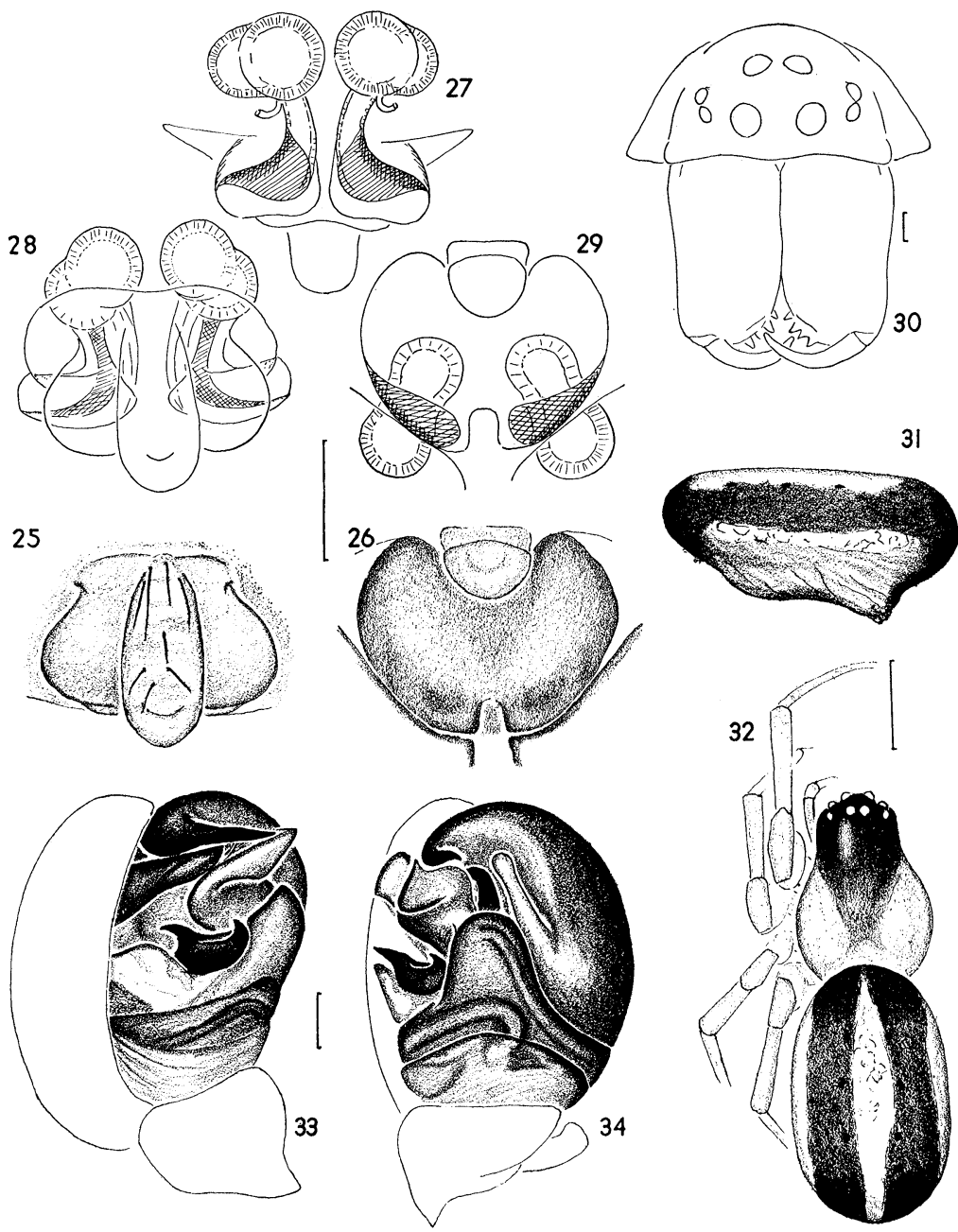

Figs. 25-34. Singa eugeni sp. n. 25-32. Female. 25-29. Epigynum. 25. Ventral. 26. Posterior. 27-29. Cleared. 27. Dorsal. 28. Ventral. 29. Posterior. 30. Face. 31. Abdomen, lateral. 32. Dorsal. 33-34. Left palpus. 33. Mesal. 34. Ventral.

Si:e Indicators: $0.1 \mathrm{~mm}$, except for Figs. $31,32,1 \mathrm{~mm}$. 
designated by Petrunkevitch, 1911, Bull. Amer. Mus. Natur. Hist., vol. 29 , p. 275. The name is of feminine gender.

Note. Both Wiehle (I93I) and Roewer's Katalog der Araneae spell the generic name Hyposinga. Roewer changed the spelling of many generic names from long accustomed usage to the spelling of that of the original author. But here Roewer changed the original spelling. Ausserer consistently spelled the name with "s" and also indicated that a main character of the subgenus is the high clypeus (hypso, Greek for high).

Diagnosis. Hypsosinga differs from Singa in having the posterior median eyes the largest (I.2-2 diameters of anterior median eyes, Figs. 52, 64, 93, 105). The ocular quadrangle is wider behind than in front, or rectangular. The clypeus height in Hypsosinga is I.5 to 3 diameters of the anterior median eyes (Figs. 52, 64, 8I, I05), but only about one diameter of the anterior median eyes in Singa. It is always slightly higher in males than females. As in Singa, but unlike most Araneus, Hypsosinga has the carapace smooth and rather wide in front, wider than the eye area (Figs. 54, 66); there is no thoracic depression, or sometimes a small longitudinal black mark in the male. Unlike many Araneus, the males of the North American species have no hooks on the first coxae. The first tibiae of males of $H$. singaeformis and $H$. groenlandica are swollen (Fig. 7I). In many araneids, it is the second tibia that is modified. The abdomen in Hypsosinga unlike that of Singa tends to be oval, widest in the middle, with either two dorsal longitudinal bands or four dark spots (Figs. 54, 66, 83, 95, 106). Like Singa, unlike Araneus, Hypsosinga frequently has the eye region black.

The epigynum differs from those of both Singa and Araneus in lacking a scape (Figs. 49, 6I, IO2). The palpus differs from that of Singa in having a smaller terminal apophysis (A) and a spur on the ventral face of the tegulum (Figs. 35, 36, 39). Hypsosinga differs from all other genera of Araneidae in having a large transparent scale attached to the base of the embolus (Fig. 69); the scale breaks off in mating and lodges in the epigynum (Figs. 99, I00; Levi, 1972). A scar remains on the embolus (Figs. 70, 98). The median apophysis is small in all species (M, Figs. 35, 38, 39). The palpal patella has two setae.

Description. All species are quite similar in general appearance and unlike Neoscona species differ more from each other in genitalic differences than in abdominal patterns. The carapace is orange, lacking hair; eye region black, and rarely in individuals, the black 
may extend to a point on thorax, or only surround eyes (H. groenlandica, Fig. 93). Sternum orange to dark brown. Legs orange, rarely with longitudinal lines in $H$. singaeformis, and very rarely banded in some individuals of $H$. rubens. Juveniles may have white pigment spots on dorsum of carapace and sometimes on sternum.

Abdomen with little hair and with two longitudinal black bands indistinctly separated by a lighter area, but fused posteriorly (Figs. 66,83 ). Bands very distinctly set off toward lighter sides (Figs. 53, $65,82)$. The dark bands are usually darkest anteriorly and posteriorly. There may only be four black spots on dorsum, or they may be completely missing; sometimes abdomen entirely black. The sides may have an additional black band (Fig. 53). Venter of abdomen black with a white longitudinal line on each side (Figs. 53, 94). Males have abdominal pattern less distinct. Smaller individuals of $H$. rubens and females of $H$. alberta may have the dorsal muscle spots sclerotized. Total length of females is $2.4-5.1 \mathrm{~mm}$, of males 2.2-3.5 mm.

Natural History. Hypsosinga make a complete orb probably with a retreat. All species are most commonly collected by sweeping vegetation. Males are mature in spring, the females throughout the season.

Distribution. Species of Hypsosinga are only known from Eurasia, North Africa and North America.

Keys to American species of Hypsosinga

Ia. Female epigynum with a median depression (Fig. I02). Male unknown; Western Canada .................................... alberta

Ib. Female epigynum with a median, raised septum (Figs. 49, 6I, 90)

2a. Epigynum with septum having sides almost parallel and septum about one-third width of epigynum (Fig. 49); male embolus long and thread-shaped (Figs. 55-57) variabilis

2b. Sides of epigynal septum not parallel, or if parallel not as wide as one-third of epigynum; male embolus short ................. 3

3a. Sides of septum almost straight, septum triangular in appearance (Figs. 76, 77); embolus of palpus long and thin, much narrower than the space surrounded by it and terminal apophysis (Figs. 87, 88)

3b. Side of septum concave (Figs. 6I, 90); embolus of palpus as wide or wider than long, wider than space surrounded by it and terminal apophysis (Figs. 70, 98) 
4a. Posterior transverse part of epigynal scape wider than length of scape (Fig. 6I); distal edge of palpal tegulum and tegulum spur smooth (Fig. 68); widespread ................. singaeformis

4b. Posterior transverse part of epigynal scape shorter than length of scape (Fig. 90); distal edge of tegulum and tegulum spur jagged (Fig. 97); Northwest Territories to Greenland

groenlandica

\section{Hypsosinga sanguinea (C. L. Koch)}

Figures 35-43

Singa sanguinea C. L. Koch, 1845, Arachniden, vol. 11, p. 155, pl. 951, ㅇ. Female holotype presumably in the Zoologisches Museum, Humboldt Universität, Berlin, not examined. Wiehle, 1931, in Dahl, Tierwelt Deutschlands, vol. 23, p. 49, figs. 69, 70,,$+ \hat{o}$. Locket and Miliidge, 1953, British Spiders, vol. 2, p. 155, figs. 103, D, E, 104, C, + , $\hat{o}$.

Hypsosinga sanguinea, - Ausserer, 1871, Verhandl. Zool. Bot. Ges. Wien, vol. 21, p. 823 .

Singa atra Kulczynski, 1885, Denkschr. Akad. Wissenschaft. Krakau, vol. 11, p. 23, pl. 9, fig. 6, + . Two female syntypes from Kamchatka in the Polish Academy of Sciences, Warsaw; examined. NEW SYNONYMY.

Note. The syntypes of Singa atra are slightly larger than specimens examined from Central Europe and the median raised part of the epigynum is slightly wider.

Natural History. This species lives close to the ground, sometimes in heather, but also in limestone areas. The web has I9-2I spokes, the center is $15 \mathrm{~cm}$ above the ground and the diameter of the web is $53 \mathrm{~mm}$. The spider remains in the center; it has no retreat. Adult males are found in May and June, females until August (Wiehle, I93 I Locket and Millidge, I953).

Distribution. Eurasia and North Africa. In the Museum of Comparative Zoology are specimens from Formosa (Taiwan).

\section{Hypsosinga variabilis (Emerton) \\ Figures 44-57; Map 2}

Singa variabilis Emerton, 1884, Trans. Connecticut Acad. Sci., vol. 6, p. 322, pl. 34, fig. 16, pl. 37, figs. 19-21,,$+ \hat{o}$. Two male and five female syntypes from New Haven, Connecticut in the Museum of Comparative Zoology; examined. McCook, 1893, American Spiders, vol. 3, p. 233, pl. 20, figs. 11-13, pl. 19, fig. 7 , + , $\hat{o}$. Kaston, 1948, Bull. Connecticut Geol. Natur. Hist. Surv., vol. 70, p. 241, figs. 760-765, ㅇ, $\hat{o}$.

Microneta distincta Banks, 1892, Proc. Acad. Natur. Sci. Philadelphia, p. 48, pl. 2, fig. 53, o. Male type from Ithaca, New York, in the Museum of Comparative Zoology; examined. NEW SYNONYMY.

Linyphia bicolor Banks, 1906, Proc. Entomol. Soc. Washington, vol. 7, p. 97. One female, two male syntypes from Olympia, Washington in the 


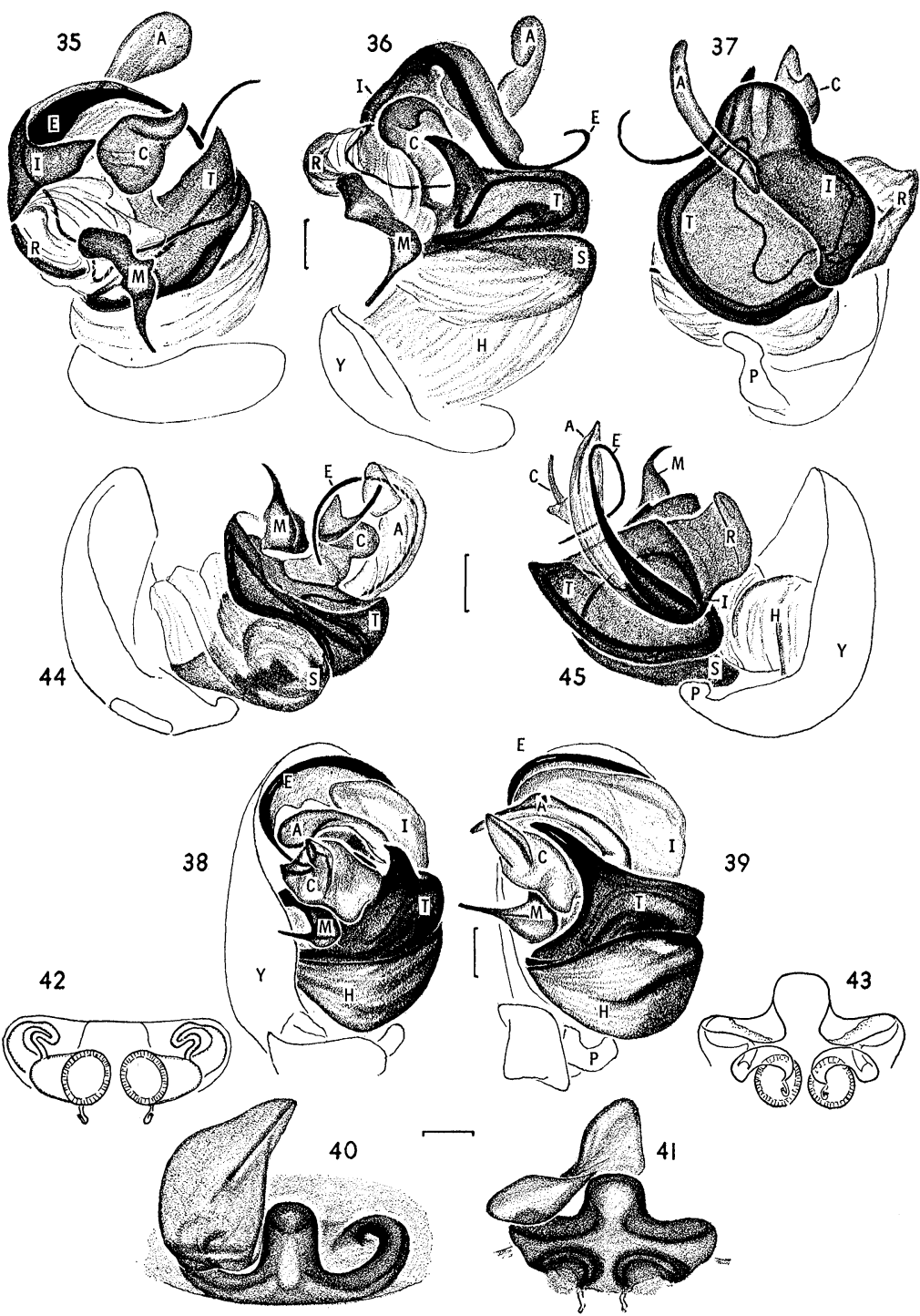

Figs. 35-43. Hypsosinga sanguinea (C. L. Koch). 35-39. Left palpus. 35-37. Expanded. 38. Submesal. 39. Ventral. 40-43. Epigynum, with a palpal scale. 40. Ventral. 41. Posterior. 42-43. Cleared. 42. Dorsal. 43. Posterior.

Figs. 44-45. Hypsosinga variabilis (Emerton), palpus, expanded.

Abbreviations: A, terminal apophysis; C, conductor; E, embolus; $\mathrm{H}$, basal hematodocha; I, stipes; $M$, median apophysis; $P$, paracymbium; $R$, radix; $S$, subtegulum; $T$, tegulum; $\mathrm{Y}$, cymbium.

Size Indicaiors: $0.1 \mathrm{~mm}$. 
Museum of Comparative Zoology; examined. Not Linyphia bicolor Nicolet, 1849. NEW SYNONYMY.

Singa cubana Banks, 1909, Rept. Centr. Exp. Sta. Cuba, vol. 2, p. 157, pl. 45, fig. 8, ․ Female holotype from Havana, Cuba, in the Museuin of Comparative Zoology; examined. NEW SYNONYMY.

Linyphia banksi Petrunkevitch, 1911, Bull. Amer. Mus. Natur. Hist., vol. 29, p. 246. New name for Lynyphia bicolor Banks, name preoccupied. NEW SYNONYMY.

Araneus varians Petrunkevitch, 1911, Bull. Amer. Mus. Natur. Hist., vol. 29, p. 323. New name for Singa variabilis because erroneously thought preoccupied by Epeira variabilis Keyserling, 1864. Not Araneus varians Thorell, 1899.

Singa melania Chamberlin and Ivie, 1947, Bull. Univ. Utah, biol. ser., vol. 10, ser. 3, p. 64. Juvenile type from Matanuska, Alaska; lost. NEW SYNONYMY.

Araneus itemvarians Bonnet, 1955, Bibliographia Araneorum, vol. 2, p. 523.

New name for Araneus varians Petrunkevitch, 1911.

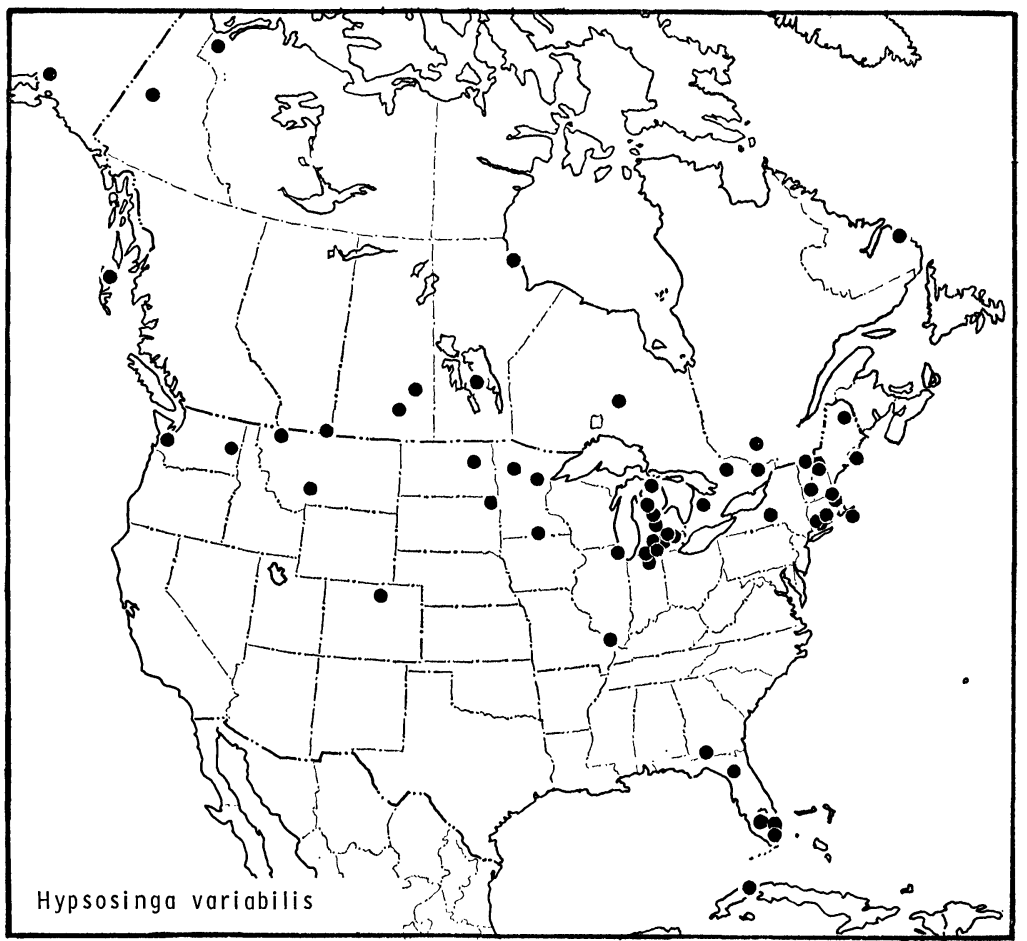

Map. 2. Distribution of Hypsosinga variabilis (Emerton). 

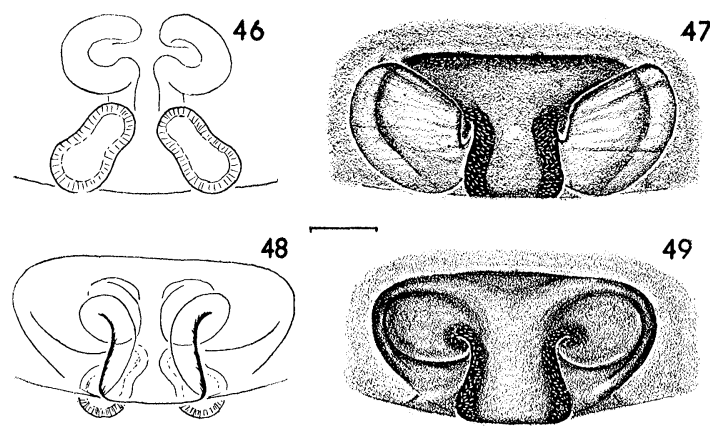

49
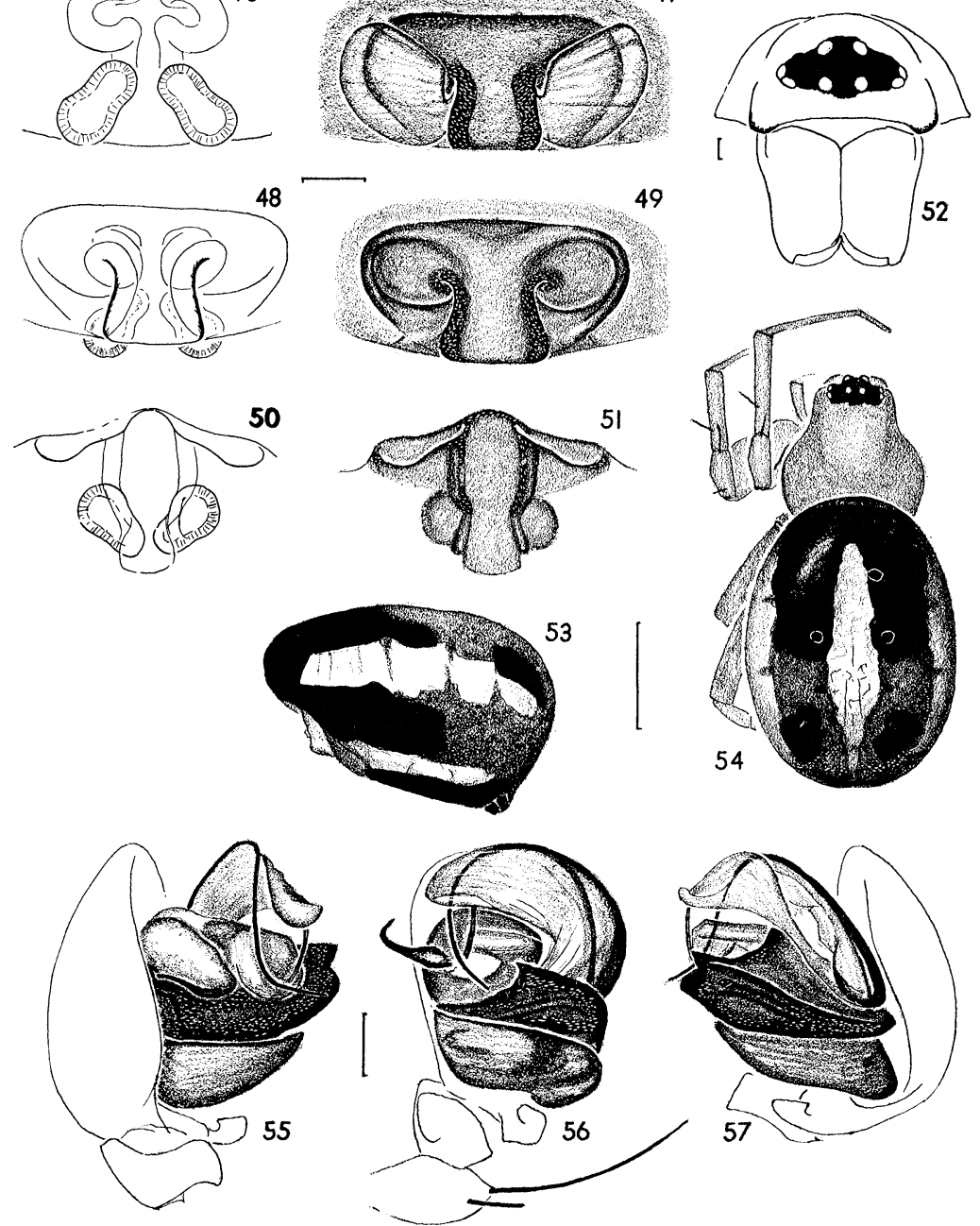

Figs. 46-57. Hypsosinga variabilis (Emerton). 46-54. Female. 46-51. Lipigynum. 46. Dorsal, cleared. 47. Ventral with scales. 48. Ventral, cleared. 49. Ventral. 50. Posterior, cleared. 51. Posterior. 52. Face. 53. Abdomen, lateral. 54. Jorsal. 55-57. Left palpus. 55. Mesal. 56. Ventral. 57. Lateral. Size Indicators: $0.1 \mathrm{~mm}$, except for Figs. 53, 54, $1 \mathrm{~mm}$. 
Note. The only character of possible diagnostic value mentioned by Chamberlin and Ivie for $S$. melania is that the anterior lateral eyes are larger than the posterior laterals. This size difference among lateral eyes may be found in $S$. variabilis and not in other species of Singa.

Description. Female from Michigan. Total length $4.0 \mathrm{~mm}$. Carapace $1.5 \mathrm{~mm}$ long, $1.3 \mathrm{~mm}$ wide. First femur, $1.2 \mathrm{~mm}$; patella and tibia, $1.5 \mathrm{~mm}$; metatarsus, $1.0 \mathrm{~mm}$; tarsus, $0.5 \mathrm{~mm}$. Second patella and tibia, $1.3 \mathrm{~mm}$; third, $0.9 \mathrm{~mm}$; fourth, $1.4 \mathrm{~mm}$.

Male from Michigan. Total length $2.2 \mathrm{~mm}$. Carapace $\mathrm{I} .3 \mathrm{~mm}$ long, 1.0 mm wide. First femur, I.2 mm; patella and tibia, I.3 mm; metatarsus, $0.9 \mathrm{~mm}$; tarsus, $0.5 \mathrm{~mm}$. Second patella and tibia, I.2 $\mathrm{mm}$; third, $0.7 \mathrm{~mm}$; fourth, $1.0 \mathrm{~mm}$.

$V$ ariation. The coloration of the abdomen is from black to yellowish white, the light specimens may have four dorsal black spots on the abdomen, rarely two bands (Fig. 54). The females are 2.9-3.9 $\mathrm{mm}$ total length, carapace $1.0-1.5 \mathrm{~mm}$ wide. Males are 2.2-2.6 mm total length, carapace I.O-I.9 mm wide. The largest specimens come from the no:thern part of the range, the smallest from the southern.

Diagnosis. Hypsosinga variabilis is closest to $H$. sanguinea of Eurasia, the long embolus (Figs. 55-57), the wide median septum of the epigynum (Figs. 47, 49) of $H$. variabilis separates it from other American species.

Natural History. The only observations are from sweeping it from a wet meadow in Minnesota, and roadside grass in Manitoba; vegetation bordering canal in Florida. The males are mature in May and June, females have been collected adult in May to July, in August to February in Florida.

Distribution. From Alaska and Cartwright, Labrador to Havana, Cuba (Map 2).

\section{Hypsosinga singaeformis (Scheffer) \\ Figures 58-7I; Map 3}

Araneus singaeformis Scheffer, 1904, Entomol. News, vol. 15, p. 259, pl. 17, figs. 4-6, + . Female syntypes from Wallace County, Kansas in the Museum of Comparative Zoology; examined.

Singa schefferi Banks, 1910, Bull. U.S. Natl. Mus., vol. 72, p. 40. New name since Araneus schefferi thought preoccupied by Epeira singaeformis Hasselt, 1882.

Singa singaeformis, - Roewer, 1942, Katalog der Araneae, vol. 1, p. 878.

Singa orotes Archer, 1951, Amer. Mus. Novitates, no. 1487, p. 41, figs. 36, $37,61, \delta$. Male holotype from Regnier, Colorado $[48 \mathrm{~km}$ south and 

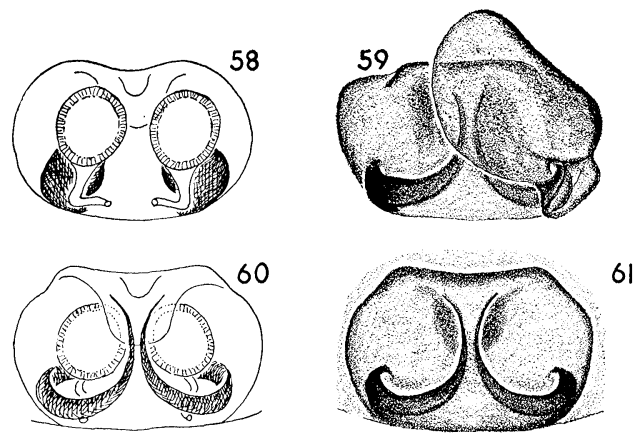

61
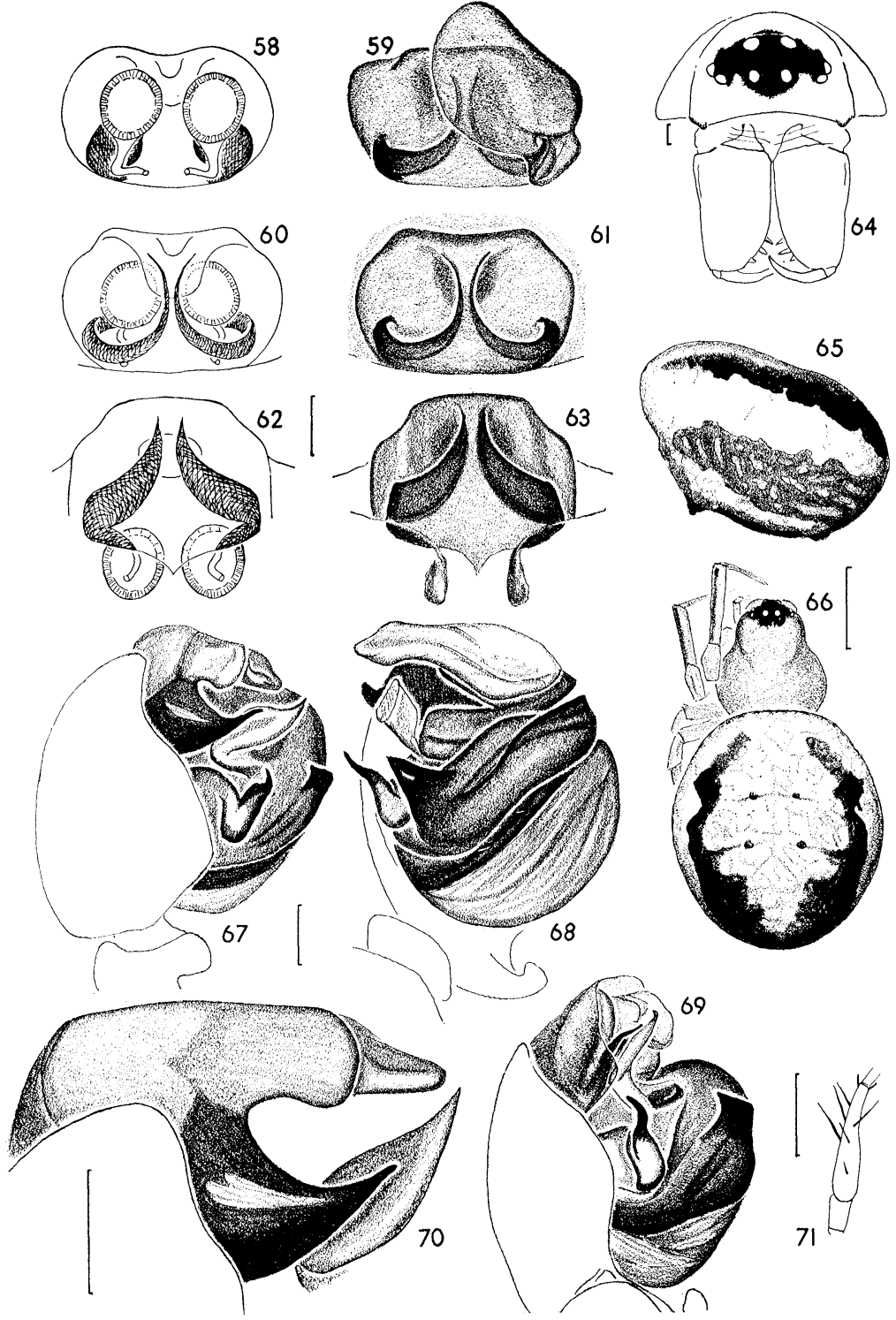

Figs. 58-71. Hypsosinga singaeformis (Scheffer). 58-66. Female. 58-63. Epigynum. 58. Dorsal, cleared. 59. Ventral with scale. 60. Ventral, cleared. 61. Ventral. 62. Posterior, cleared. 63. Posterior. 64. Face. 65. Abdomen, lateral. 66. Dorsal. 67-69. Left palpus. 67. Mesal. 68. Ventral. 69. Mesal with scale. 70. Embolus, terminal apophysis and conductor. 71. Left tibia and patella of male, ventral.

Size Indicators: $0.1 \mathrm{~mm}$, except for Figs. 65, 66, 71, $1 \mathrm{~mm}$. 
slightly west of Springfield, Baca County, $1400 \mathrm{~m}$ elev.] in the American Museum of Natural History; examined. NEW SYNONYMY.

Araneus singiformis, - Bonnet, 1955, Bibliographia Araneorum, vol. 2, p. 600.

Note. Figure 69 was prepared from the holotype of S. orotes, a specimen that was parasitized by a nematomorph worm.

Description. Female from South Dakota. Total length $3.8 \mathrm{~mm}$. Carapace $1.5 \mathrm{~mm}$ long, I.2 $\mathrm{mm}$ wide. First femur, I.2 $\mathrm{mm}$; patella and tibia, I.4 $\mathrm{mm}$; metatarsus, $0.9 \mathrm{~mm}$; tarsus, $0.4 \mathrm{~mm}$. Second patella and tibia, I.2 $\mathrm{mm}$; third, $0.9 \mathrm{~mm}$; fourth, I. $3 \mathrm{~mm}$.

Male from South Dakota. The first tibia is swollen at the proximal end (Fig. 7I). Total length $2.7 \mathrm{~mm}$. Carapace $\mathrm{I} .3 \mathrm{~mm}$ long, I.3 $\mathrm{mm}$ wide. First femur, I.2 $\mathrm{mm}$; patella and tibia, $1.6 \mathrm{~mm}$; metatarsus, $0.9 \mathrm{~mm}$; tarsus, $0.5 \mathrm{~mm}$. Second patella and tibia, I.4 $\mathrm{mm}$; third, $0.9 \mathrm{~mm}$; fourth, $1.3 \mathrm{~mm}$.

Variation. The total length of females is $2.9-5.0 \mathrm{~mm}$, the carapace width, I.O-I.6 mm. The males are $2.4-3.5 \mathrm{~mm}$ total length, carapace I.I-I.4 mm wide.

Diagnosis. Females can be distinguished by the concave margin on each side of the median septum of the epigynum, and the wide anteriorly curved posterior margin on each side (Fig. 6I), while the septum of $H$. rubens is more or less triangular. The embolus of the palpus is short (Figs. 67, 70) and the terminal apophysis above the embolus at a right angle to its long axis (Figs. 67, 70), separating the species from $H$. rubens, which has a long embolus.

Natural History. The species has been collected by beating pines in Alberta, sweeping meadow in South Dakota, from meadow and litter in woods in Arkansas, a grassy field in California, in old weedy overgrown ranch at Yuma, Arizona, a strawberry field in Arkansas, and grass in Louisiana. Males are mature in June and July, females from May to August, and February in Florida.

Distribution. From Hondo, Alberta, northern New England to Santa Catalina Island, California, San Antonio, Texas and 2.5 miles southwest of Archer, Florida (Map 3).

\section{Hypsosinga rubens (Hentz) \\ Figures 72-88; Map 3}

Epeira rubens Hentz, 1847, J. Boston Natur. Hist. Soc., vol. 5, p. 477, pl. 31, fig. 18, $ᄋ$. Female holotype from Alabama in the Boston Natural History Society, destroyed.

Singa maculata Emerton, 1884, Trans. Connecticut Acad. Sci., vol. 6, p. 323, pl. 37, fig. 18, + , $\hat{o}$. One female, one male syntypes from New Haven, Connecticut, in the Museum of Comparative Zoology; examined. 


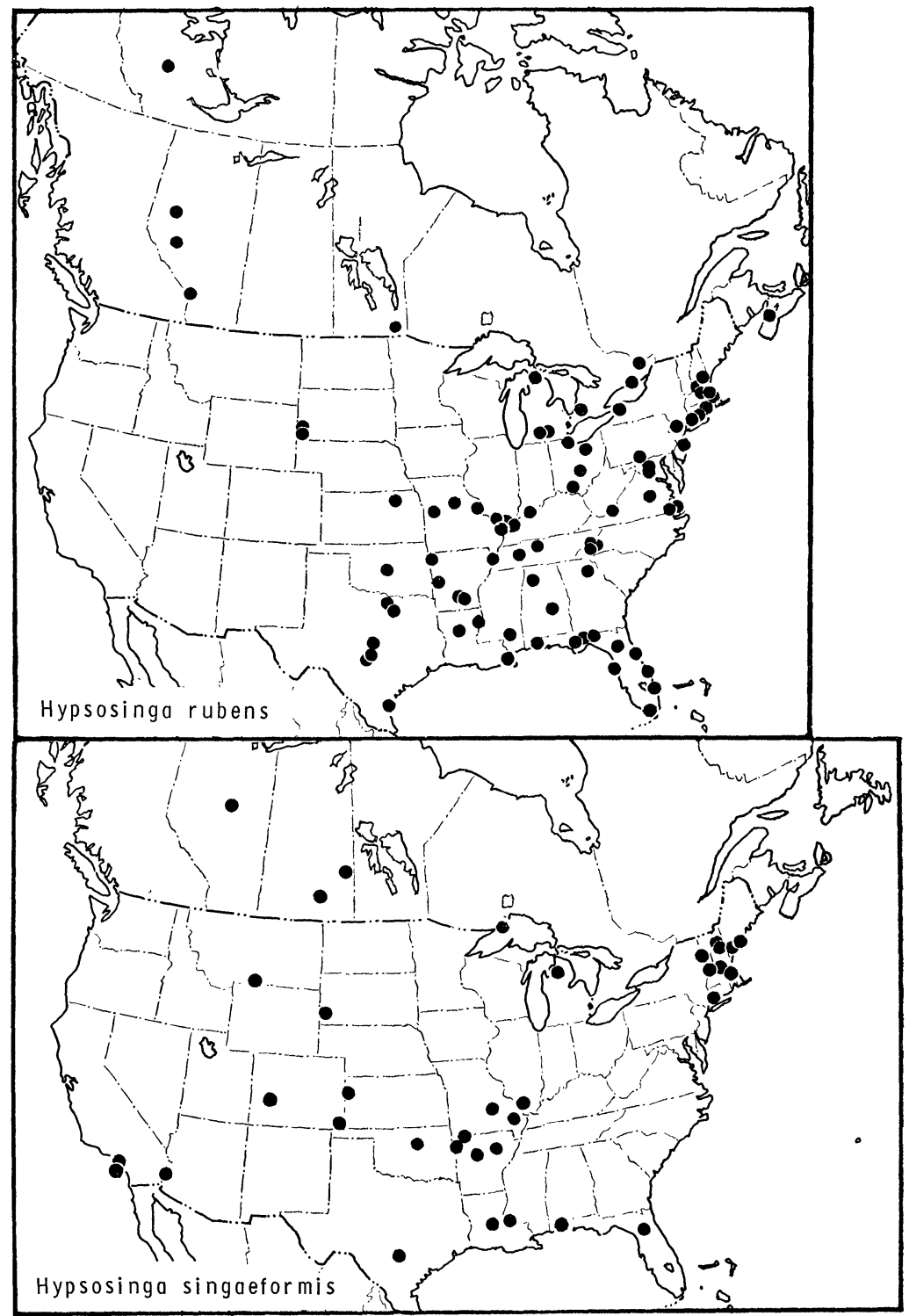

Map 3. Distribution of Hypsosinga rubens (Hentz) and Hypsosinga singaeformis (Scheffer). 
Keyserling, 1892, Spinnen Amerikas, vol. 4, p. 285, pl. 14, figs. 210, + . Not Singa maculata Thorell, 1875.

Singa nigripes Keyserling, 1884, Verhandl. Zool. Bot. Ges. Wien, vol. 33, p. 655 , pl. 21, fig. 7, o. Female holotype from Indian River, Florida (Marx collection) in the United States National Museum; examined. 1893, Spinnen Amerikas, vol. 4, p. 290, pl. 15, fig. 214, + . McCook, 1893, American Spiders, vol. 3, p. 232, pl. 19, figs. 5, 6, ㅇ, ㅅ․ NEW SYNONYMY.

Singa modesta Banks, 1896, Trans. Amer. Entomol. Soc., vol. 23, p. 70. Female lectotype here designated from Lake Worth, Florida in the Museum of Comparative Zoology; examined. NEW SYNONYMY.

Singa truncata Banks, 1901, J. New York Entomol. Soc., vol. 9, p. 188. New name for Singa maculata Emerton, preoccupied. Kaston, 1948, Bull. Connecticut Geol. Natur. Hist. Surv., vol. 70, 241, figs. 746, 766. Singa hentzi Banks, 1907, Ann. Rep. Dept. Geol. Natur. Res. Indiana, p. 740, fig. 20, + . Female lectotype from Cannelton, Indiana, in the Museum of Comparative Zoology; examined. NEW SYNONYMY.

Araneus hentzi, - Petrunkevitch, 1911, Bull. Amer. Mus. Natur. Hist., vol. 29, p. 296. Bonnet, 1955, Bibliographia Araneorum, vol. 2, p. 516.

Araneus rubens, - Petrunkevitch, 1911, Bull. Amer. Mus. Natur. Hist., vol. 29, p. 313. Bonnet, 1955, Bibliographia Araneorum, vol. 2, p. 587.

Araneus modestus, - Petrunkevitch, 1911, Bull. Amer. Mus. Natur. Hist., vol. 29, p. 304. Bonnet, 1955, Bibliographia Araneorum, vol. 2, p. 546.

Araneus nigripes, - Petrunkevitch, 1911, Bull. Amer. Mus. Natur. Hist., vol. 29, p. 306. Bonnet, 1955, Bibliographia Araneorum, vol. 2, p. 549. Araneus tusus Petrunkevitch, 1911, Bull. Amer. Natur. Hist., vol. 29, p. 321. New name for Singa truncata Banks thought preoccupied by Epeira truncata Keyserling, 1865 (= Edricus truncatus).

Singa rubens, - Archer, 1940, Paper Alabama Mus. Natur. Hist., no. 14, p. 38 , pl. 2, fig. 3 , 9 .

Singa tusa, - Chamberlin and Ivie, 1944, Bull. Univ. Utah (biol. ser.), vol. 35, p. 109.

Araneus truncatus, - Bonnet, 1955, Bibliographia Araneorum, vol. 2, p. 619.

Note: Fig. 20 of Banks, 1907, was printed upside down. The specimen described has banded legs. My Figures 74, 77, 78 and 80 were prepared from the holotype of Singa nigripes.

Description. Female from South Dakota. Total length $3.2 \mathrm{~mm}$. Carapace I.4 mm long, I.2 mm wide. First femur, I.O $\mathrm{mm}$; patella and tibia, $1.3 \mathrm{~mm}$; metatarsus, $0.8 \mathrm{~mm}$; tarsus, $0.5 \mathrm{~mm}$. Second patella and tibia, I.2 $\mathrm{mm}$; third, $0.8 \mathrm{~mm}$; fourth, I.2 $\mathrm{mm}$.

Male from South Dakota. The first tibia is very slightly thicker proximally than distally. Total length $2.7 \mathrm{~mm}$. Carapace $1.3 \mathrm{~mm}$ long, I.2 $\mathrm{mm}$ wide. First femur, I.2 $\mathrm{mm}$; patella and tibia, I.5 $\mathrm{mm}$; metatarsus, $0.8 \mathrm{~mm}$; tarsus, $0.5 \mathrm{~mm}$. Second patella and tibia, I.2 $\mathrm{mm}$; third, $0.8 \mathrm{~mm}$; fourth, $1.2 \mathrm{~mm}$.

Variation. At first it seemed quite clear to me that there are at least two species, a large one with long ducts in the female (Fig. 78) 

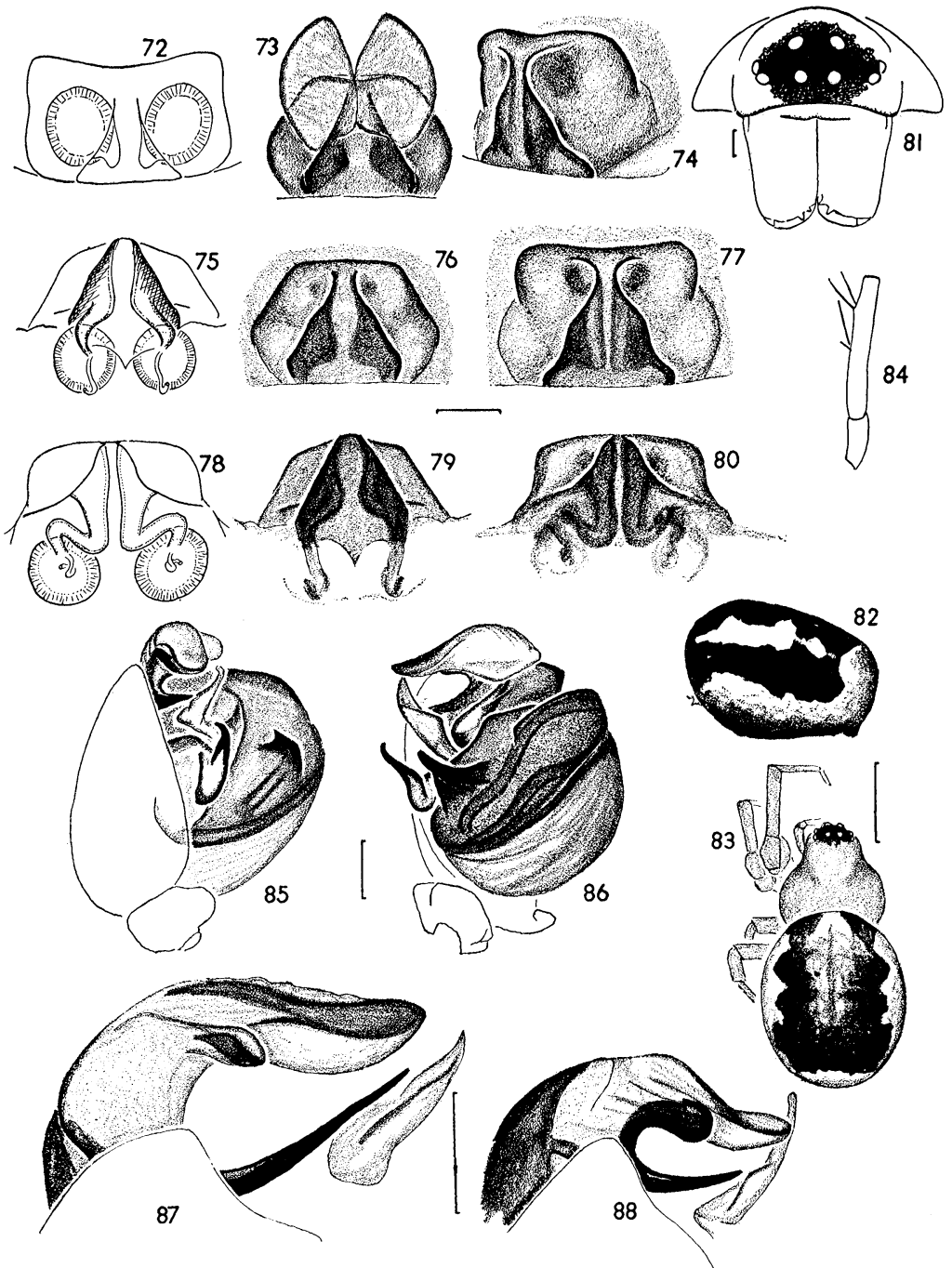

Figs. 72-88. Hypsosinga rubens (Hentz). 72-83. Female. 72-80. Epigynum. 72. Ventral, cleared. 73. Ventral with scales. 74. Subventral. 75. Posterior, cleared. 76, 77. Ventral. 78. Posterior, cleared. 79-80. Posterior. 73, 75, 76, 79. (South Dakota). 74, 77, 78, 80. (Florida). 81. Face. 82. Abdomen, lateral. 83. Dorsal. 84. Male, first patella and tibia, ventral. 85-88. Left palpus. 85. Mesal. 86. Ventral. 87, 88. Embolus and terminal apophysis, extremes of variation.

Size Indicators: $0.1 \mathrm{~mm}$, except for Figs. $82,83,1 \mathrm{~mm}$. 
and longer embolus in the male (Fig. 87), and a smaller one (Figs. $75,88)$. The specimens of the first collections studied were carefully separated by these criteria. The smaller ones had the abdomen all light in the south, legs black, the abdomen black in the north. Larger individuals had the abdomen well patterned. A female from Mountain Lake, Virginia (H. K. Wallace collection) had an epigynum with the duct longer on one side than the other, and threw doubt on my simple classification. As more specimens were determined I found that I became more and more arbitrary in deciding what was large and had long ducts and long embolus. I decided that measurements of the carapace diameter on a large series of females should be taken. To my surprise I got a normal distribution and not two peaks as I had expected. The large size and color morphological variation are found throughout the range of the species. It is not geographic variation. Many collections had smaller and larger individuals collected together; the larger ones tend to have longer ducts and emboli. The smaller males have relatively larger muscle scars on the abdomen. I assume that the larger ones go through more molts than smaller ones; variation in number of molts is common in spiders. The variation resembles that found in certain theridiid spiders, e.g. Thymoites unimaculatus (Emerton), but in Thymoites it is geographic variation. The type of Singa hentzi has banded legs, as do some other specimens from Indiana and Illinois.

The size variation of females is total length $2.4-5.1 \mathrm{~mm}$; carapace width $0.9-1.6 \mathrm{~mm}$; males total length $2.2-3.2 \mathrm{~mm}$; carapace width $0.8-1.5 \mathrm{~mm}$.

Diagnosis. The median piece of the epigynum is more or less triangular (Figs. 72, 76, 77) while that of $H$. singaeformis is concave on each side. The embolus (Figs. 87, 88) is much longer than that of $H$. singaeformis and the terminal apophysis of a different shape.

Natural History. Most collections have been made by sweeping in pinewoods, woods, forest edge, shrubs, herbaceous vegetation, alfalfa, and clover fields, but specimens have been obtained from leaf litter and under bark, and between loose siding of a cottage. The males are mature from April to May, February in southern states, June in the North. There is one record of a male from Alabama in August. Females have been collected from March to July. 

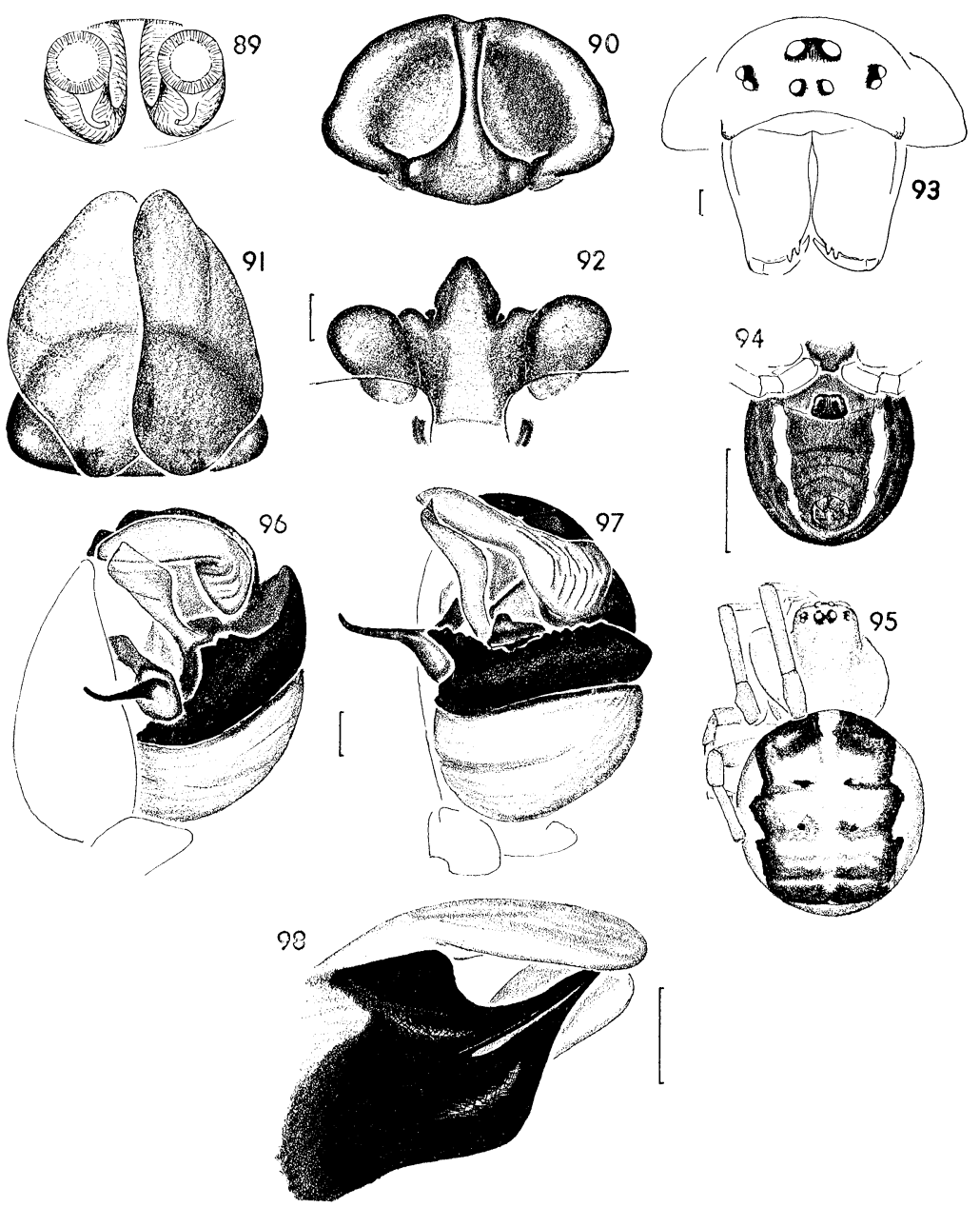

Figs. 89-98. Hypsosinga groenlandica Simon. 89-95. Female. 89-92. Epigynum. 89. Dorsal, cleared. 90. Ventral. 91. Ventral with scales. 92. Posterior. 93. Face. 94. Venter of abdomen. 95. Dorsum. 96-98. Left palpus. 96. Mesal. 97. Ventral. 98. Embolus and terminal apophysis.

Size Indicators: $0.1 \mathrm{~mm}$, except Figs. 94, 95, $1 \mathrm{~mm}$. 
Distribution. From Wrigley, Northwest Territories to Aldershot, Nova Scotia and Goose Island State Park, Arkansas County, Texas to Florida (Map 3).

\section{Hypsosinga groenlandica Simon \\ Figures 89-98, Map 4}

Hypsosinga groenlandica Simon, 1889, Bull. Soc. Zool. France, vol. 14, p. 290. Juvenile holotype from Fjord de Kokortok, Greenland in the Muséum National d'Histoire Naturelle, Paris, examined.

Singa (Hypsosinga) groenlandica Holm, 1960, Ark. Zool., ser. 2, vol. 12, p. 512, figs. 2, + . Holm, 1967, Medd. Grønland, vol. 184, p. 69, figs. 86, 87 , ㅇ.

Description. Female from Northwest Territories. Total length $3.2 \mathrm{~mm}$. Carapace $1.5 \mathrm{~mm}$ long, $1.3 \mathrm{~mm}$ wide. First femur, I.2 $\mathrm{mm}$; patella and tibia, I.4 mm; metatarsus, $0.9 \mathrm{~mm}$; tarsus, 0.5 $\mathrm{mm}$. Second patella and tibia, $1.3 \mathrm{~mm}$; third, $0.9 \mathrm{~mm}$; fourth, I. $2 \mathrm{~mm}$.

Males. The dorsum of the abdomen is brown, lightly sclerotized. The muscle scars are sclerotized. The carapace is smooth with a thoracic longitudinal line. The first tibia is swollen and slightly bent, with strong macrosetae. Total length $3.5 \mathrm{~mm}$. Carapace $\mathrm{r} .6$ $\mathrm{mm}$ long, I.4 $\mathrm{mm}$ wide. First femur, I. $3 \mathrm{~mm}$; patella and tibia, I.7 mm; metatarsus, I.O $\mathrm{mm}$; tarsus, $0.6 \mathrm{~mm}$. Second patella and tibia, I. $6 \mathrm{~mm}$; third, r.o $\mathrm{mm}$; fourth, $\mathrm{I} .4 \mathrm{~mm}$.

Diagnosis. The shape of the median epigynal septum (Fig. 90) is diagnostic. The sides of the narrow septum are concave and the posterior transverse part is not as wide as that of $H$. singaeformis. The male can be separated from other species by the toothed edge of the tegulum (Fig. 97). All males were collected in pitfall traps and have their palpi expanded, probably as a result of ethylene glycol. They have been illustrated as if contracted.

Records. Northwest Territories: Salmita Mines, $64^{\circ} \mathrm{O} 5^{\prime} \mathrm{N}$ : I I I ${ }^{\circ} I^{\prime} \mathrm{W}$, ㅇ (Chilcott); $20 \mathrm{mi}$. E of Tuktoyaktuk, 우 $0^{\pi} \sigma^{\pi} \mathrm{July}$ i97I (W. R. M. Mason), Lac Maunoire, IO-I8 July I969, $20^{*}$ (G. E. Shewell), "Pan trap." The other records mapped are those published by Holm (Map 4).

\section{Hypsosinga alberta sp. $n$.} Figures 99-106; Map 4

Holotype. Female from Cypress Hills, Alberta, 400 feet (I30 m) altitude, 30 .June I969 (B. M. Rolseth) in the Canadian National Collection, Ottawa. The name is a noun in apposition. 

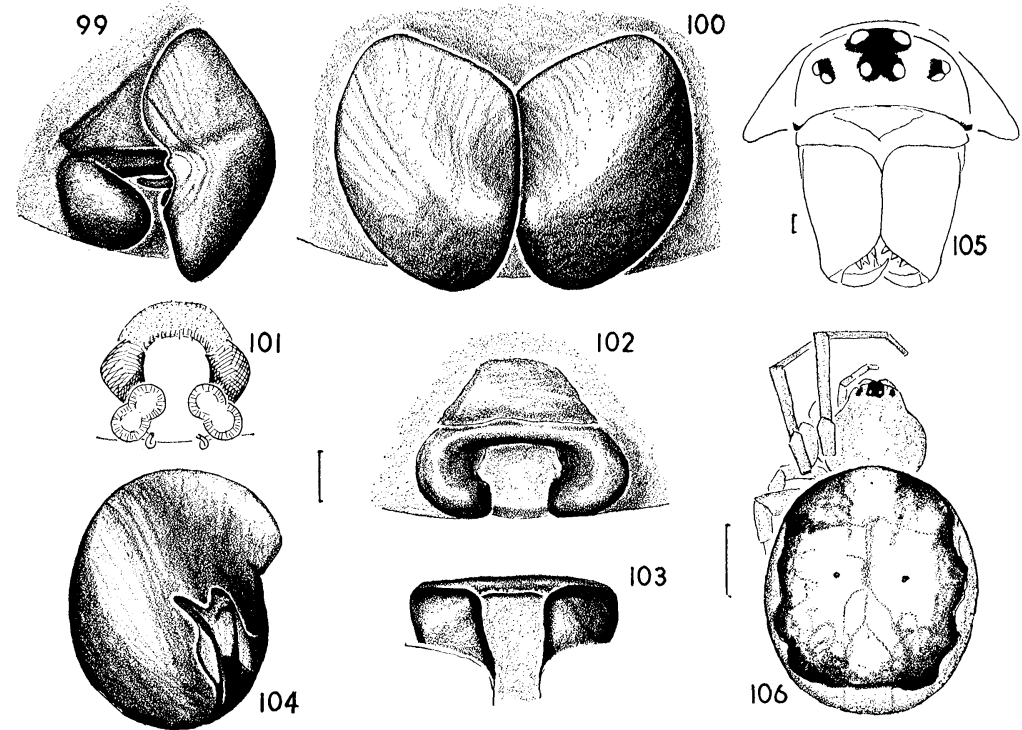

Figs. 99-106. Hypsosinga alberta sp. n., female. Figs. 99-103. Epigynum. 99. Subventral, with one scale. 100. Ventral with scales. 101. Dorsal, cleared. 102. Ventral. 103. Posterior. 104. Left scale, dorsal view. 105. Face. 106. Dorsal.

Size Indicators: $0.1 \mathrm{~mm}$, except Fig. 106, $1 \mathrm{~mm}$.

Description. Female. Carapace yellow, slightly reddish on sides. Sternum brown. Legs yellow. Dorsum of abdomen marked as in other IIypsosinga (Fig. Io6), often entirely black. Venter black with one light band on each side. Posterior median eyes I.2 diameters of anteriors, laterals 0.8 diameter of anterior medians. Anterior median eyes one and one-half diameters apart, two diameters from laterals. The posterior row is slightly recurved as seen from above. The clypeus is one and one-half to two diameters of the anterior median eyes. Total length $5.0 \mathrm{~mm}$. Carapace $1.7 \mathrm{~mm}$ long, I. $6 \mathrm{~mm}$ wide. First femur, I. $5 \mathrm{~mm}$; patella and tibia, I. $8 \mathrm{~mm}$; metatarsus, I.I $\mathrm{mm}$; tarsus, $0.7 \mathrm{~mm}$. Second patella and tibia, I. $6 \mathrm{~mm}$; third, I.I $\mathrm{mm}$; fourth, $1.6 \mathrm{~mm}$.

Diagnosis. The female Hypsosinga alberta can be distinguished from other species by its lack of a raised median sclerotized septum (Fig. I02) and, if mated, by the heavily sclerotized scales covering the epigynum (Fig. IOO). 


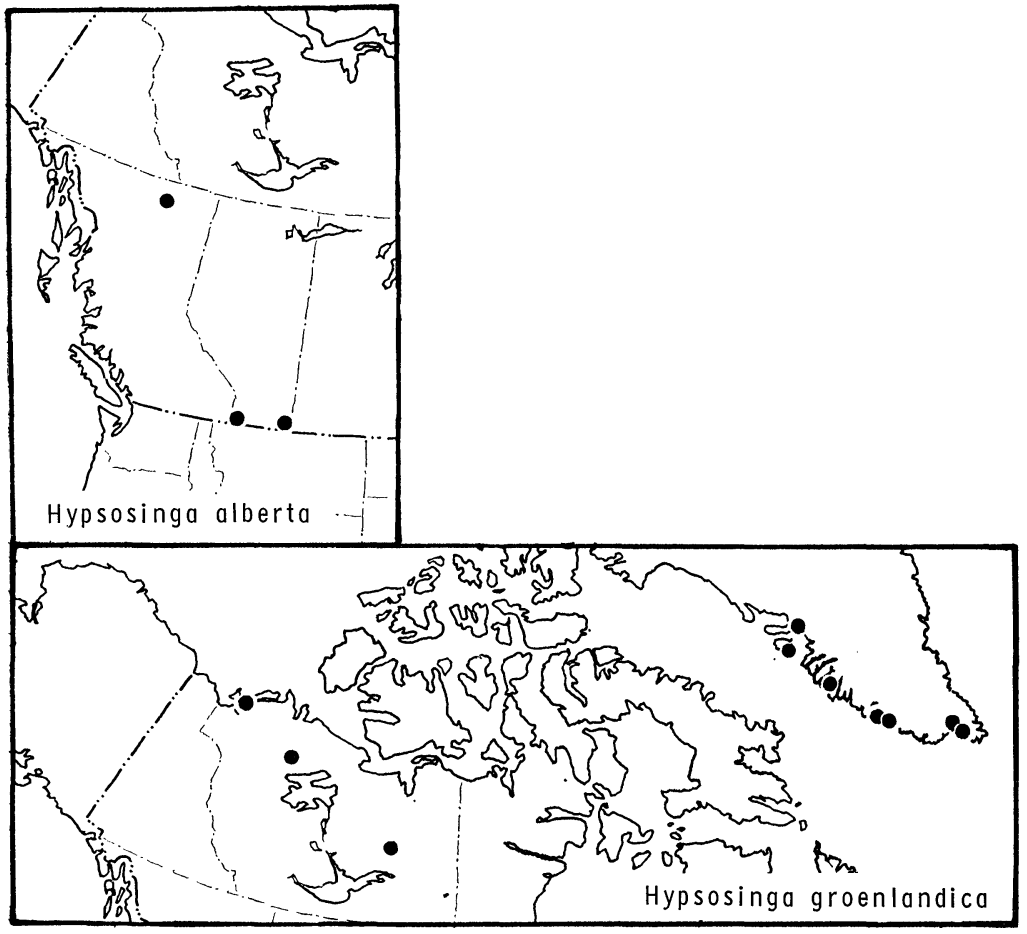

Map 4. Distribution of Hypsosinga groenlandica Simon and Hypsosinga alberta sp. $\mathrm{n}$.

Variation. The abdomen of many specimens is black, the carapace and legs brown. Females varied from $4.5-5.0 \mathrm{~mm}$ in total length, carapace width from I.4- $.6 \mathrm{~mm}$.

Records. Paratypes have been collected from Alberta, Waterton Lakes National Park, IO mi. E of Red Rock Canyon, 4200 m, I 8 July 1968, 2 9 (D. G. Wales). British Columbia. Summit Lake, mile 392, Alaska Highway, o, 3i July i959 (R. E. Leech). 

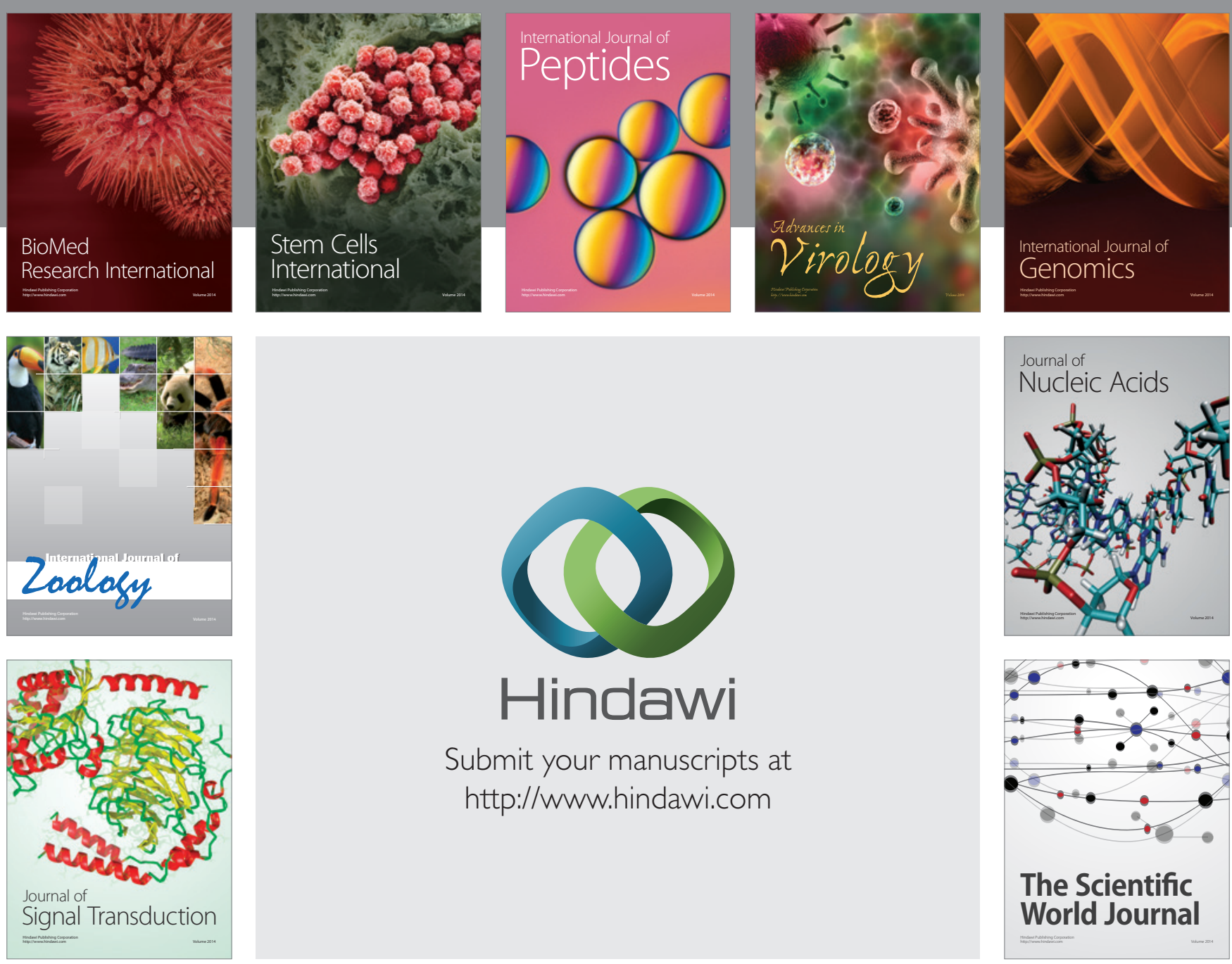

Submit your manuscripts at

http://www.hindawi.com
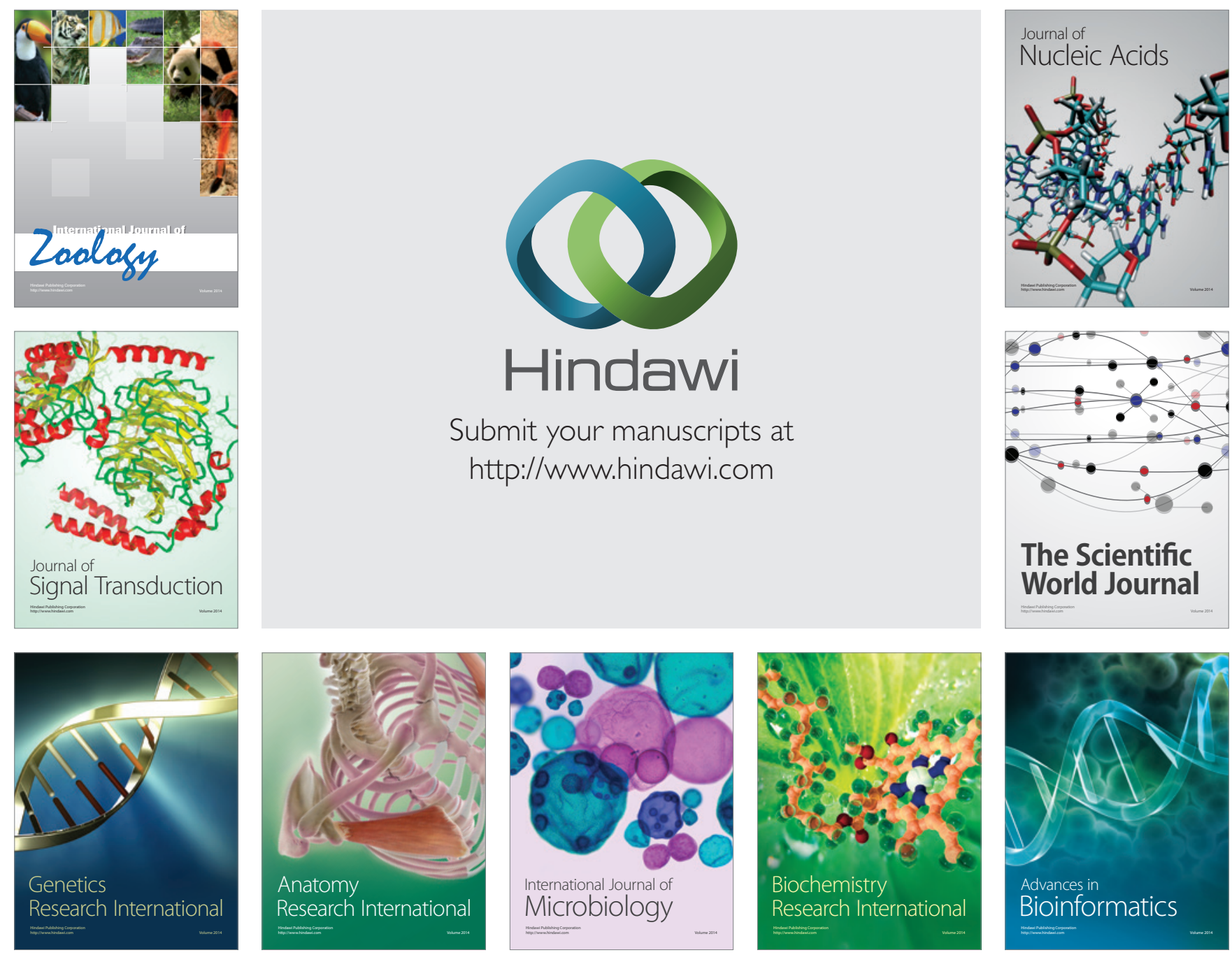

The Scientific World Journal
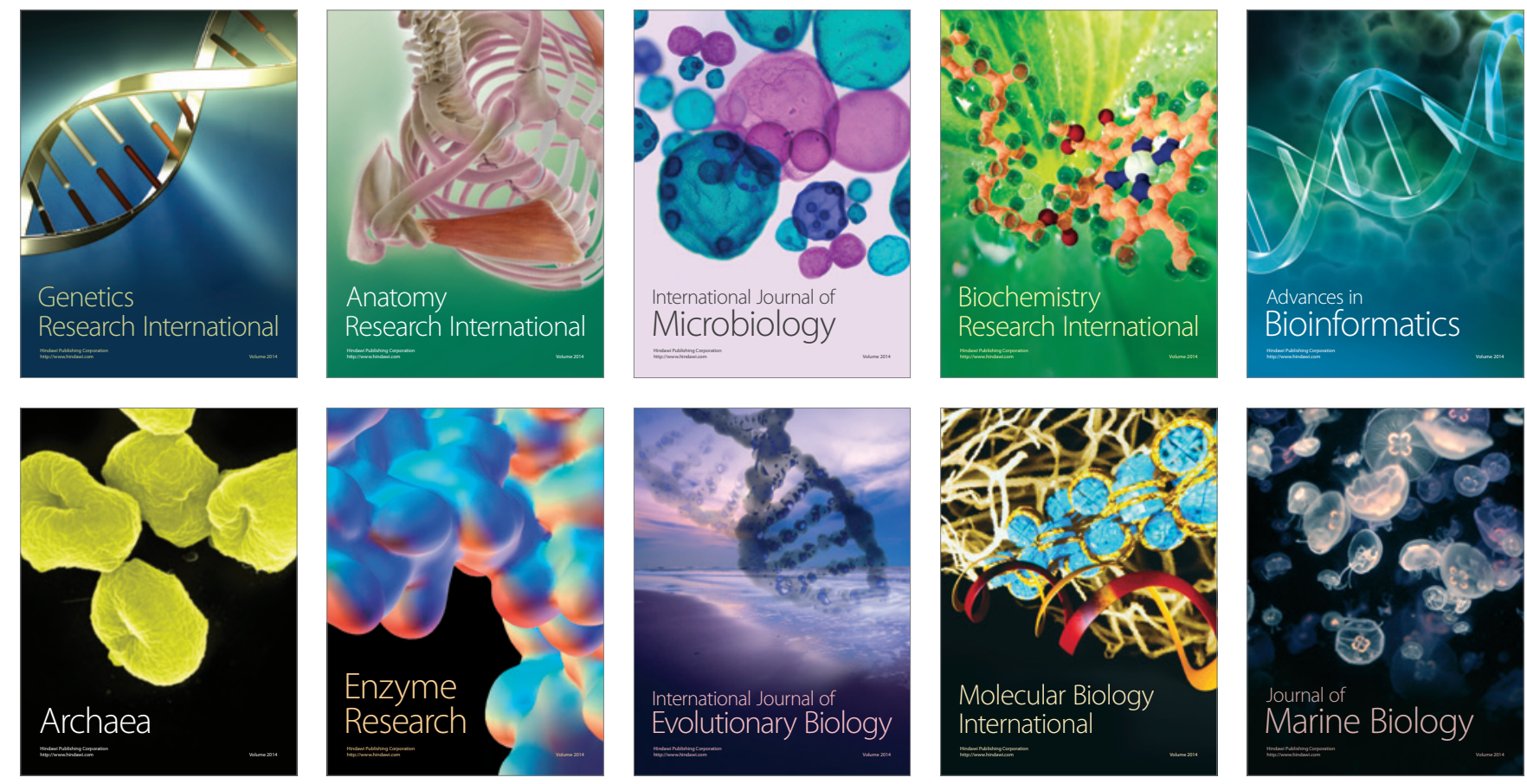